\title{
Expanding the universe of categorical syllogisms: A challenge for reasoning researchers
}

\author{
MAXWELL J. ROBERTS \\ University of Essex, Colchester, England
}

\begin{abstract}
Syllogistic reasoning, in which people identify conclusions from quantified premise pairs, remains a benchmark task whose patterns of data must be accounted for by general theories of deductive reasoning. However, psychologists have confined themselves to administering only the 64 premise pairs historically identified by Aristotle. By utilizing all combinations of negations, the present article identifies an expanded set of 576 premise pairs and gives the valid conclusions that they support. Many of these have interesting properties, and the identification of predictions and their verification will be an important next step for all proponents of such theories.
\end{abstract}

A categorical syllogism consists of a pair of premises and a conclusion. Each of these contains one of four possible quantifiers, which are shown along with their Euler circle meanings in Table 1. Together, the premises describe the relationships between three entities (A, B, and C), with the first premise linking the $\mathrm{A}$ and $\mathrm{B}$ terms, the second linking the $\mathrm{B}$ and $\mathrm{C}$ terms, and the conclusion linking the $\mathrm{A}$ and $\mathrm{C}$ terms (traditionally, in the $\mathrm{C}-\mathrm{A}$ direction). For example:

$$
\begin{aligned}
& \text { all } \mathrm{B} \text { are } \mathrm{A} \\
& \text { all } \mathrm{C} \text { are } \mathrm{B} \\
& \text { therefore, all } \mathrm{C} \text { are } \mathrm{A} \text {. }
\end{aligned}
$$

This is a valid syllogism. Given that the premises are true and no sets are empty, the conclusion must also be true. The ordering of information in the premises is of importance logically and is coded by the figure of the syllogism. In the above example, the ordering in the premises is BA-CB, and this is said to be Figure 1 (see Table 1 for an outline of the notation). If just the premises were presented in the example above, this would be denoted as AA1. However, care should be taken when comparing studies, because conventions vary.

There are 64 possible premise pair combinations: 4 possible quantifiers for the first premise $\times 2$ possible term orders $\times 4$ possible quantifiers for the second premise $\times 2$ possible term orders (see Table 1 ). Nineteen of these combinations give a valid conclusion in the $\mathrm{C}-\mathrm{A}$ direction. If $\mathrm{A}-\mathrm{C}$ conclusions are permitted also, a further eight premise pairs also yield one. Although categorical syllogisms are no longer of key importance to logicians, this topic continues to be included in logic courses. In addition, their solution requires the interpretation of language,

Correspondence concerning this article should be addressed to M. J. Roberts, Department of Psychology, University of Essex, Wivenhoe Park, Colchester, Essex CO4 3SQ, England (e-mail: mjr@essex.ac.uk). the integration of different pieces of information, and the identification of new information that was not explicitly stated. These are all essential components of inference, and it is, therefore, not surprising that categorical syllogisms continue to be one of several tasks against which general theories of reasoning are benchmarked (e.g., Chater \& Oaksford, 1999; Johnson-Laird \& Byrne, 1991; Polk \& Newell, 1995).

When investigating performance, psychologists usually present only pairs of premises, asking subjects to decide what conclusions (if any) follow from them, via either multiple choice or free response tasks. Recent work has also permitted subjects to identify conclusions in either the $\mathrm{C}-\mathrm{A}$ or the $\mathrm{A}-\mathrm{C}$ direction, thus allowing the possibility of nine different responses to each premise pair (for a review of a range of studies that have taken place, see Evans, Newstead, \& Byrne, 1993). Irrespective of task format, identifying valid conclusions for premise pairs can be extremely difficult. If all 64 combinations are administered, typically one half to one third of the responses will be correct. However, errors tend to be highly systematic.

\section{Theories of Syllogistic Reasoning}

Roberts and Sykes (2005) have identified three broad categories of theories that seek to explain patterns of performance at syllogistic reasoning tasks. Surface or heuristic explanations posit that most people fail to engage with the task and identify conclusions solely on the basis of the surface features of the items. Hence, people applying atmosphere or matching strategies (see, e.g., Wetherick \& Gilhooly, 1995) or the more sophisticated probability heuristics model (Chater \& Oaksford, 1999) draw conclusions simply from the quantifiers present. For example, all in both premises implies all as the conclusion, hence leading to errors where this response is not valid.

In contrast, proponents of representation explanations assert that people do attempt to represent and reason with information from the premises. Roberts, Newstead, and Griggs (2001) further subdivided these explanations into 
Table 1

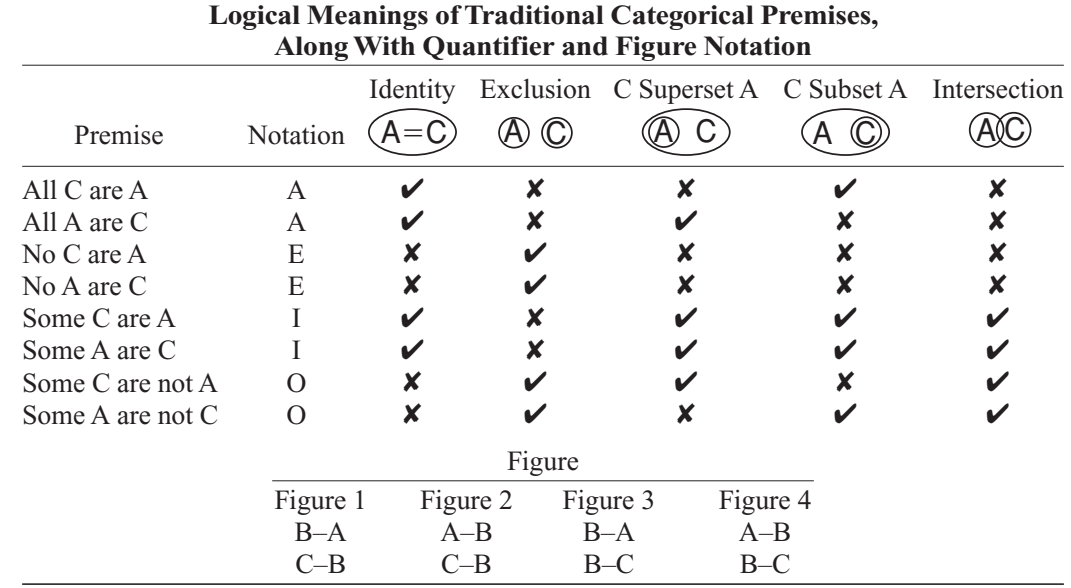

Note-In actual experimental tasks, additional words are often used-for example, none of the $C$ are $A$ rather than no $C$ are $A$ and some of the $C$ are not $A$ rather than some $C$ are not $A$. Reading across, this table shows the Euler circles compatible with, and implied by, each premise. For example, all $C$ are $A$ is compatible with just two situations: the identity set and where $\mathrm{C}$ is a subset of A. All $A$ are $C$ is also compatible with two situations: this time, the identity set and where $\mathrm{C}$ is a superset of $\mathrm{A}$. Reading down, this table shows the conclusions that each Euler circle is compatible with. For example, the identity set is compatible with all $C$ are $A$, all $A$ are $C$, some $C$ are $A$, and some $A$ are $C$.

two separate categories. Search theories generally suggest that errors occur due to the inevitable difficulty of executing multistep procedures. Syllogisms that require the most steps to solve are the hardest, either because errors are more likely to be made for longer processing sequences (e.g., PSYCOP, Rips, 1994; mental models, Johnson-Laird \& Byrne, 1991) or because longer sequences are less likely to be executed fully (e.g., verbal reasoning, Polk \& Newell, 1995; see also Evans, Handley, Harper, \& Johnson-Laird, 1999; but see also Roberts, 2006). A more specific source of error is suggested by interpretation theories: Errors in identifying conclusions arise from systematic errors with interpreting quantifiers. For example, all may be interpreted as indicating just the identity set, not the subset relationship (see Table 1). Proponents of such theories include Erickson (1974) and Roberts and colleagues (Roberts, 2006; Roberts et al., 2001). These misinterpretations appear to stem from a need to simplify items, rather than prior experience with natural language biasing people's interpretations (Roberts, 2004).

The final category constitutes conclusion identification explanations, in which it is suggested that errors may occur when conclusions are identified, even where information has been correctly and exhaustively represented. Often, these take the form of arbitrary biases against certain responses, such as some ... not (Chater \& Oaksford, 1999) or no valid conclusion (e.g., Revlis, 1975). However, Roberts and Sykes (2005) have suggested that difficulties in making such responses may arise as a natural consequence of the need to execute multistep procedures, even where information is represented flawlessly.

\section{Expanding the Universe of Categorical Syllogisms}

Even if there is a dominant reasoning strategy, applied by most people when solving syllogisms, its identifica- tion has proved surprisingly difficult. One reason for this is that when people attempt to identify conclusions from all of the 64 traditional premise pairs, the patterns of data are well established. This means that theories focus on predicting already known data but are then short of material for cross-validation. They therefore have not been subjected to investigations with risky predictions within the domain of categorical reasoning. Hence, we are in the frustrating situation of multiple theories predicting similar patterns of errors, albeit for different reasons. For example, Chater and Oaksford's (1999) probability heuristics model predicts responses identical to those that are expected when people reason logically from certain quantifier misinterpretations (Roberts et al., 2001).

There are a number of solutions to this difficulty. For example, it is possible to devise new categorical reasoning tasks (see, e.g., Roberts \& Sykes, 2005) or to use dual-task methodology to investigate working memory requirements (e.g., Bacon, Handley, \& Newstead, 2005; Gilhooly, 2005). Alternatively, an attempt can be made to investigate response latencies (e.g., Espino, Santamaria, \& Garcia-Madruga, 2000). A further possibility is to pay closer attention to individual differences than is usually the case (e.g., Bacon et al., 2005; Ford, 1995; Gilhooly, Logie, Wetherick, \& Wynn, 1993). However, in this article, it is proposed to expand considerably the number of categorical premise pairs - from the traditional 64 to 576 - by applying all permutations of negations.

The full negations paradigm has been applied for several decades within the domain of conditional reasoning (e.g., Evans \& Lynch, 1973) but has not previously been applied by psychologists to categorical premise pairs. Hence, only the four quantifiers historically identified by Aristotle have been used, even though there are 12 possibilities. One exception to this is the work of Stenning 
(2002; Stenning \& Yule, 1997), who investigated so-called $U$-conclusions: some not-C are not- $A$ and some not- $A$ are not-C. Permitting subjects to identify these gives a valid conclusion to eight traditional premise pairs that previously did not have one (see Appendix G). However, this quantifier was not used for the actual premise pairs.

The full set of quantifiers potentially available for syllogistic reasoning tasks is shown in Table 2. In order to encompass the expanded set, a revised notation system is required, and suggested abbreviations are also shown in Table 2 . Hence, the premise pair previously known as AE1-all $B$ are $A$, no $C$ are $B$-will now be designated $\mathrm{A}[\mathrm{aa}] \mathrm{N}[\mathrm{aa}] 1$ : The lowercase letters in brackets denote whether the A, B, or $\mathrm{C}$ terms are affirmed or negated. Several of the new quantifiers are, in fact, logically identical to the current ones. For example, N[an]A[an]1 (no $B$ are not $-A$, all $C$ are not- $B$ ) is identical to $\mathrm{A}[\mathrm{aa}] \mathrm{N}[\mathrm{aa}] 1$ (all $B$ are $A$, no $C$ are $B$ ), even though the surface features appear to differ.

As is shown in Table 2, three of the new quantifiers are logically equivalent to previous ones, but this leaves five that are different and have not previously been investigated. One deterrent to using them is undoubtedly the difficulty in identifying valid conclusions. However, the author has identified these by using a subtraction method (see Appendix A), and the solutions are presented in Appendices B-H. A surprising number of premise pairs yield valid conclusions (expressible using traditional quantifiers for 368 out of the 576).

\section{Why Are the New Premise Pairs Interesting?}

Expanding the range of items available for syllogistic reasoning studies not only offers a general means by which theories may be cross-validated. It is also possible to identify interesting properties of the expanded set, which will enable direct tests of certain theories.

Surface features can be changed without changing valid conclusions. Several quantifiers are logically equivalent to others, and it is therefore possible to manipulate items so that the underlying logic remains the same but the surface features differ. For example, consider the equivalent premise pairs $\mathrm{A}[\mathrm{aa}] \mathrm{A}[\mathrm{aa}] 1$ versus $\mathrm{N}[\mathrm{an}] \mathrm{N}[\mathrm{an}] 1$ :

all of the beekeepers are artists

all of the chefs are beekeepers

versus

none of the beekeepers are not artists

none of the chefs are not beekeepers.

In both cases, the valid conclusion is the same-all of the chefs are artists - but if people are responding according to the atmosphere of the premises, we might expect fewer instances of this for the second premise pair. This would particularly be the case if subjects responded via multiple choice options containing the traditional quantifiers. It is harder to make predictions for Chater and Oaksford's (1999) probability heuristics model. Although they have identified various heuristics, they have not detailed their

Table 2

Full Set of Quantified Premises and Notation, Also Showing Which Premises Are Reversible and Which Are Logically Equivalent

\begin{tabular}{|c|c|c|c|c|}
\hline Premise & Reversible? & $\begin{array}{c}\text { New } \\
\text { Notation }\end{array}$ & $\begin{array}{c}\text { Equivalent } \\
\text { Premise }\end{array}$ & $\begin{array}{c}\text { Weaker } \\
\text { Equivalent }\end{array}$ \\
\hline All $\mathrm{X}$ are $\mathrm{Y}$ & & $\mathrm{A}[\mathrm{aa}] \mathrm{XY}$ & $\mathrm{N}[\mathrm{an}] \mathrm{XY}$ & $\mathrm{S}[\mathrm{aa}] \mathrm{XY}$ \\
\hline All $\mathrm{X}$ are not-Y & yes & $\mathrm{A}[\mathrm{an}] \mathrm{XY}$ & $\mathrm{N}[\mathrm{aa}] \mathrm{XY}$ & $\mathrm{S}[\mathrm{an}] \mathrm{XY}$ \\
\hline All not-X are $Y$ & & $\mathrm{~A}[\mathrm{na}] \mathrm{XY}$ & $\mathrm{N}[\mathrm{nn}] \mathrm{XY}$ & $\mathrm{S}[\mathrm{na}] X Y$ \\
\hline All not-X are not-Y & & $\mathrm{A}[\mathrm{nn}] \mathrm{XY}$ & $\mathrm{N}[\mathrm{na}] \mathrm{XY}$ & $\mathrm{S}[\mathrm{nn}] \mathrm{XY}$ \\
\hline No $\mathrm{X}$ are $\mathrm{Y}$ & yes & $\mathrm{N}[\mathrm{aa}] \mathrm{XY}$ & $\mathrm{A}[\mathrm{an}] \mathrm{XY}$ & $\mathrm{S}[\mathrm{an}] \mathrm{XY}$ \\
\hline No $\mathrm{X}$ are not-Y & & $\mathrm{N}[\mathrm{an}] \mathrm{XY}$ & $\mathrm{A}[\mathrm{aa}] \mathrm{XY}$ & $\mathrm{S}[\mathrm{aa}] \mathrm{XY}$ \\
\hline No not-X are $\mathrm{Y}$ & & $\mathrm{N}[\mathrm{na}] \mathrm{XY}$ & $\mathrm{A}[\mathrm{nn}] \mathrm{XY}$ & $\mathrm{S}[\mathrm{nn}] \mathrm{XY}$ \\
\hline No not-X are not-Y & & $\mathrm{N}[\mathrm{nn}] \mathrm{XY}$ & $\mathrm{A}[\mathrm{na}] \mathrm{XY}$ & $\mathrm{S}[\mathrm{na}] \mathrm{XY}$ \\
\hline Some $\mathrm{X}$ are $\mathrm{Y}$ & yes & $\mathrm{S}[\mathrm{aa}] \mathrm{XY}$ & & \\
\hline Some $\mathrm{X}$ are not- $\mathrm{Y}$ & & $\mathrm{S}[\mathrm{an}] \mathrm{XY}$ & $\mathrm{S}[\mathrm{na}] \mathrm{YX}$ & \\
\hline Some not-X are $\mathrm{Y}$ & & $\mathrm{S}[\mathrm{na}] \mathrm{XY}$ & $\mathrm{S}[\mathrm{an}] \mathrm{YX}$ & \\
\hline Some not-X are not-Y & yes & $\mathrm{S}[\mathrm{nn}] \mathrm{XY}$ & & \\
\hline
\end{tabular}

Note-For reversible quantifiers, it is possible to swap the terms in a premise (but not the negations) without changing the meaning. The only new quantifiers that are reversible are $\mathrm{A}[\mathrm{an}]$ and S[nn]. For example, all $X$ are not- $Y$ is equivalent to all $Y$ are not- $X$. "Weaker equivalents" are quantifiers that are also true if the stronger one is true. Hence, if all not- $X$ are not- $Y$ is true, so is some not- $X$ are not- $Y$. Despite their validity, weaker equivalents are generally not reported where a stronger quantifier is also valid. The notation for single premises needs to indicate the order of its terms. However, for premise pairs, the figure number will continue to be used (see Table 1). 
implementation. If their operation is based on a simple keyword search, fewer all of the chefs are artists conclusions would likewise be expected. If not, it is not clear what predictions might be made.

Minor changes to surface features can alter valid conclusions. Changes to the placement of negations can have considerable effects on valid conclusions. For example, compare $\mathrm{A}[\mathrm{aa}] \mathrm{A}[\mathrm{an}] 4$ with $\mathrm{A}[\mathrm{aa}] \mathrm{A}[\mathrm{na}] 4$ :

all of the people who are artists are beekeepers all of the people who are beekeepers are not chefs

valid conclusion: none of the chefs are artists versus

all of the people who are artists are beekeepers

all of the people who are not beekeepers are chefs

valid conclusion: some of the chefs are not artists.

Repositioning the negation has changed the conclusion, and it is therefore important to know whether subjects are sensitive to this. If so, this would be further evidence against surface theories of reasoning. In the case of the probability heuristics model, it is again not clear whether it could make any predictions at all, other than that both sets of premise pairs should be responded to identically. Predicted differences would require the relative informativeness of all not- $B$ are $C$ versus all $B$ are not- $C$ to be calculated.

Items can be identified that should be easy to solve. Mental models theory posits that people construct integrated representations of the premises that are analogous to Euler circles/Venn diagrams. Items are predicted to be difficult where it is necessary to construct multiple representations in order to identify valid conclusions. Although there are some difficulties in determining precisely how many representations are required for individual premise pairs (e.g., Hardman, 1996; Rips, 1994), it is nonetheless possible to identify new premise pairs that definitely require the construction of just one representation in order to identify a conclusion. These are the items in which the premises permit just one Euler circle relationship between the $\mathrm{A}$ and the $\mathrm{C}$ terms (see Appendices C2, C4, D, and E4). Such items should, therefore, be particularly easy to solve. Where other single versus multiple representation items can also be identified, this would provide a further test of whether the use of mental models can be said to be the dominant strategy for reasoning from categorical premise pairs.

\section{Does the Full Negations Approach Present Any Difficulties?}

Although the new premise pairs present many possibilities to reasoning researchers, there are some potential pitfalls to their use. However, as long as these are understood, they will not present serious difficulties.

Difficulties with response collection. Increasing the number of quantifiers used potentially adds complexity to response collection. Conclusion evaluation tasks remain straightforward, as do multiple choice tasks, although it may be of interest to manipulate the options available. Conclusion production tasks are more problematic, since there is a greater variety of responses that can be made and, possibly, more scope than usual for errors in the response generation process. Researchers may, therefore, wish to instruct subjects to minimize the numbers of negations used in their responses. However, in reality, there would be a major difficulty only if the increased variety of response collection formats led to difficulty in comparing studies between researchers, especially since this can influence item difficulty (Hardman \& Payne, 1995).

Difficulties with negations. The new quantifiers involve negations - up to three of them in a single premise - and the difficulties that these present when inferences are made are well documented (e.g., Wason, 1972). In general, negated information is more difficult to process because of the additional processing steps involved, rather than because of people's rejecting the information altogether (e.g., MacLeod, Hunt, \& Mathews, 1978). Hence, the presence of negations in the new quantifiers need not make premise pairs incomprehensible, and there are several reasons why the use of such items should not be ruled out.

Three of the new quantifiers are only single-negated. These quantifiers should, therefore, be no more difficult to comprehend than the two traditional single-negated ones: no $X$ are $Y$, and some $X$ are not $Y$.

Double-negated premises are frequently used for propositional reasoning tasks. Subjects have been struggling for many years with such statements as if Tom is not in Paris, then Mary is not in London and either Tom is not in Paris, or Mary is not in London, or both. Although performance at these can be worse than that for nonnegated items, they are by no means intractable (e.g., Evans, Legrenzi, \& Girotto, 1999; Evans et al., 1993; Roberts, 2002).

Negated statements equivalent to premises containing the new quantifiers are comprehensible and sometimes psychologically necessary. Such statements as all people not involved in the school play must write an extra essay and all people who are not on an academic payscale are not eligible for the USS pension scheme can be relatively easily comprehended, and it is often not possible to rewrite such statements, omitting the negations, without changing their meanings subtly.

Subjects have been able to identify $U$-conclusions in previous studies. For a task in which such conclusions were potentially reportable, approximately $50 \%$ of the answers to items with U-conclusions were correct (Stenning \& Yule, 1997).

Overall, this leaves only the sole triple-negated quantifier, no not- $X$ are not- $Y$ as being particularly intractable, and without any obvious utility in day-to-day language. However, even if this is the case and double-negated quantifiers also turn out to be difficult to comprehend, this leads to another prediction that can be tested: that the surface features of items will particularly determine responses in such circumstances. The plausibility of this prediction has been established by recent investigations into the relationship between task format and strategy 
usage. For categorical syllogisms, if task format is varied so as to increase working memory load, there is a tendency for subjects to retreat to less demanding strategies (e.g., Gilhooly, 2005). Similarly, Roberts and Sykes (2005) suggested a reconciliation between Chater and Oaksford's (1999) probability heuristics model and theories in which it is suggested that an attempt is made to represent and process the information presented (e.g., PSYCOP, Rips, 1994; mental models, Johnson-Laird \& Byrne, 1991). This is in part derived from work by Stanovich and West (1998): Roberts and Sykes suggested that simple heuristics, based on surface features of the premises, may supply plausible initial responses. The extent to which these may be modified or overturned by the subsequent application of further reasoning procedures depends on the demands of the task and/or the cognitive ability of the subject.

Difficulties with quantifier interpretations. Ambiguous quantifiers are not new, and answers expected in the light of particular misinterpretations (but correct application of logic thereafter) are relatively easy to identify. Hence Roberts et al. (2001) reported evidence to suggest systematic misinterpretations of traditional syllogistic quantifiers. There may also be a potential for misinterpretations of the new quantifiers, but detection of these should likewise be relatively straightforward.

Shakespearean interpretations. All that glisters is not gold is not intended to mean that nothing that glisters is gold. Technically, a less poetic but logically correct assertion would be that some things that glister are not gold. Similarly, more contemporary assertions, such as all businessmen are not criminals, are also conceivable. One possibility is that such statements are intended only for use in particular contexts and that these interpretations are, therefore, less likely for syllogistic reasoning tasks with arbitrary content. Even if this is not the case and a Shakespearean interpretation is routinely applied to, for example, the $\mathrm{A}[\mathrm{aa}] \mathrm{A}[\mathrm{an}] 2$ premise pair:

all of the artists are beekeepers

all of the chefs are not beekeepers,

then, rather than the expected valid conclusion none of the chefs are artists, we would expect the answer to be derived from the premise pair A[aa]S[an]2:

all of the artists are beekeepers

some of the chefs are not beekeepers,

yielding the conclusion some of the chefs are not artists instead.

Existential negation assumptions. A key to identifying valid conclusions to premise pairs is the assumption that instances of A, B, and C exist. However, for the new quantifiers, there is some leeway in their interpretation, depending on whether it is assumed that instances of not-A, not-B, or not-C exist. It is reasonable to assume that where a negation is explicitly stated-for example, some not- $A$ are not- $B$ - a subject will assume that instances of not-A and not-B exist (leaving the existence of not- $\mathrm{C}$ open in this case). Task instructions and syntax can emphasize the need to make these assumptions. For example, all of the people who are not chefs are not beekeepers is probably more likely to lead to an assumption that people exist who are neither chefs nor beekeepers than does all nonchefs are nonbeekeepers. All solutions to syllogisms presented in the Appendices make this assumption: that examples of explicitly negated entities exist.

Interestingly, if this assumption is made, a number of premise pairs yield no valid conclusion, because the premises are mutually exclusive (see Appendix H). For example, taking $\mathrm{A}[\mathrm{aa}] \mathrm{A}[\mathrm{nn}] 4$ :

all of the people who are artists are beekeepers

all of the people who are not beekeepers are not chefs.

If we assume that instances of nonbeekeepers and nonchefs exist, the second premise effectively asserts that there must exist artists who are neither beekeepers nor chefs. However, the first premise asserts that every artist must be a beekeeper, thus giving a contradiction. It is difficult to predict subjects' answers to such items unless it is expected that they will respond particularly on the basis of surface features when faced with difficult items. If they do not, experience with such items might cause any assumptions concerning the existence of explicitly stated negated terms to cease. If we do not assume that explicitly negated terms exist, so that there need not be nonbeekeepers who are nonchefs, all of the people who are not beekeepers are not chefs becomes equivalent to all of the people who are chefs are beekeepers, and the premise pair therefore becomes equivalent to $\mathrm{A}[\mathrm{aa}] \mathrm{A}[\mathrm{aa}] 2$ :

all of the people who are artists are beekeepers

all of the people who are chefs are beekeepers.

Overall, if people do not assume that instances of explicitly stated negations must exist, this effectively modifies their quantifier interpretations. It is, therefore, straightforward to identify a set of alternative predicted responses that might be made in the light of this.

\section{The Challenge for Reasoning Researchers}

Solutions to all 576 possible premise pairs have been identified. Obviously, it would not be possible to test individuals with the entire item set, but attention has been drawn to particularly interesting items that may be used to distinguish between different theories of reasoning. It is likely that other items will have interesting properties too. Expanding the range of categorical premise pairs therefore presents a strong challenge to reasoning researchers, especially those who advocate particular theories as primary explanations of people's performance. It will be necessary for them to show that current theories - which account for patterns of data on the traditional 64-item set adequately well-generalize to the wider item set with minimal ad hoc additions. It may also be the case that certain theories will need to be specified more precisely in order to be able to make any predictions at all. Alternatively, if theorists wish to decline this invitation, sound reasons will be required as to why they need not account 
for the enlarged set. There is no obvious a priori reason why subjects should be able to understand a sentence such as some of the chefs are not beekeepers and yet have difficulty with all of the people who are not chefs are beekeepers. Hence, attempting to evade the issue of what exactly is predicted carries a risk: It could lead to an accusation that the relevant theories lack sufficient generality even to account fully for complete versions of laboratory tasks, let alone the complexities of the real world.

\section{REFERENCES}

Bacon, A., Handley, S. J., \& Newstead, S. E. (2005). Verbal and spatial strategies in reasoning. In M. J. Roberts \& E. J. Newton (Eds.), Methods of thought: Individual differences in reasoning strategies (pp. 81-105). Hove, U.K.: Psychology Press.

Chater, N., \& OAKsford, M. (1999). The probability heuristics model of syllogistic reasoning. Cognitive Psychology, 38, 191-258.

ERICKSON, J. R. (1974). A set analysis theory of behavior in formal syllogistic reasoning tasks. In R. L. Solso (Ed.), Theories in cognitive psychology: The Loyola symposium (pp. 305-329). Hillsdale, NJ: Erlbaum.

Espino, O., Santamaria, C., \& Garcia-Madruga, J. A. (2000). Figure and difficulty in syllogistic reasoning. Current Psychology of Cognition, 19, 417-428.

Evans, J. S. B. T., Handley, S. J., Harper, C. N. J., \& JohnsonLAIRD, P. N. (1999). Reasoning about necessity and possibility: A test of the mental model theory of deduction. Journal of Experimental Psychology: Learning, Memory, \& Cognition, 25, 1495-1513.

Evans, J. S. B. T., Legrenzi, P., \& Girotto, V. (1999). The influence of linguistic form on reasoning: The case of matching bias. Quarterly Journal of Experimental Psychology, 52A, 185-216.

Evans, J. S. B. T., \& LYNCH, J. S. (1973). Matching bias in the selection task. British Journal of Psychology, 64, 391-397.

Evans, J. S. B. T., Newstead, S. E., \& Byrne, R. M. J. (1993). Human reasoning: The psychology of deduction. Hove, U.K.: Psychology Press.

ForD, M. (1995). Two modes of mental representation and problem solution in syllogistic reasoning. Cognition, 54, 1-71.

GiLhooly, K. J. (2005). Working memory and strategies in reasoning. In M. J. Roberts \& E. J. Newton (Eds.), Methods of thought: Individual differences in reasoning strategies (pp. 57-80). Hove, U.K.: Psychology Press.
Gilhooly, K. J., Logie, R. H., Wetherick, N. E., \& Wynn, V. (1993). Working memory and strategies in syllogistic-reasoning tasks. Memory \& Cognition, 21, 115-124.

HaRDMAN, D. K. (1996). Mental models: The revised theory brings new problems. Behavioral \& Brain Sciences, 19, 542-543.

Hardman, D. K., \& Payne, S. J. (1995). Problem difficulty and response format in syllogistic reasoning. Quarterly Journal of Experimental Psychology, 48A, 945-975.

Johnson-Laird, P. N., \& Byrne, R. M. J. (1991). Deduction. Hove, U.K.: Psychology Press.

MacLeod, C. M., Hunt, E. B., \& Mathews, N. N. (1978). Individual differences in the verification of sentence-picture relationships. Journal of Verbal Learning \& Verbal Behavior, 17, 493-507.

Polk, T. A., \& Newell, A. (1995). Deduction as verbal reasoning. Psychological Review, 102, 533-566.

REVLIS, R. (1975). Syllogistic reasoning: Logical decisions from a complex database. In R. J. Falmagne (Ed.), Reasoning: Representation and process in children and adults (pp. 93-133). Hillsdale, NJ: Erlbaum.

RIPS, L. J. (1994). The psychology of proof. Cambridge, MA: MIT Press.

RoBERTS, M. J. (2002). The elusive matching bias effect in the disjunctive selection task. Experimental Psychology, 49, 89-97.

RoberTs, M. J. (2004). Heuristics in reasoning: Making deduction simple. In R. J. Sternberg \& J. P. Leighton (Eds.), The nature of reasoning (pp. 234-272). Cambridge: Cambridge University Press.

Roberts, M. J. (2006). Falsification and mental models: It depends on the task. In W. Schaeken, A. Vandierendonck, \& G. d'Ydewalle (Eds.), The mental models theory of reasoning: Refinement and extensions (pp. 85-113). Mahwah, NJ: Erlbaum.

Roberts, M. J., Newstead, S. E., \& Griggs, R. A. (2001). Quantifier interpretation and syllogistic reasoning. Thinking \& Reasoning, 7, 173-204.

Roberts, M. J., \& Sykes, E. D. A. (2005). Categorical reasoning from multiple diagrams. Quarterly Journal of Experimental Psychology, 58A, 333-376.

Stanovich, K. E., \& West, R. F. (1998). Cognitive ability and variation in selection task performance. Thinking \& Reasoning, 4, 193-231.

STENNing, K. (2002). Seeing reason. Oxford: Oxford University Press.

StenNing, K., \& Yule, P. (1997). Image and language in human reasoning: A syllogistic illustration. Cognitive Psychology, 34, 109-159.

Wason, P. C. (1972). In real life, negatives are false. Logique et Analyse, 57-58, 19-38.

Wetherick, N. E., \& Gilhooly, K. J. (1995). “Atmosphere,” matching, and logic in syllogistic reasoning. Current Psychology, 14, 169-178. 
APPENDIX A

Solving Syllogisms Using Venn Diagrams and a Subtraction Method

One way to conceptualize categorical syllogisms is to do so in terms of Venn diagrams, illustrated by Figures A1-A4. For the three sets A, B, and C, membership is denoted by filled regions on three overlapped circles. This gives seven different regions, each denoting a unique set membership (e.g., one region denotes members of only Set A, another denotes members of both Sets A and B but not Set C, and so on). There are, therefore, 128 unique combinations of filled regions, each denoting the existence of different combinations of set membership. Nineteen of these contain at least one empty set, and so only the remaining 109 are of interest when categorical syllogisms are solved (see Figure A1). As Figure A1 shows, if we are interested only in the possible relationships between Sets A and C, these 109 Venn diagrams can be categorized into just five different Euler circle relationships.

The following Venn diagrams all contain at least one empty set, and are not normally considered when identifying solutions to categorical syllogisms:

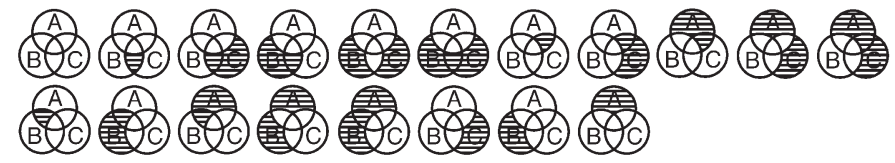

The following Venn diagrams are compatible with the identity relationship between $A$ and $C$ :

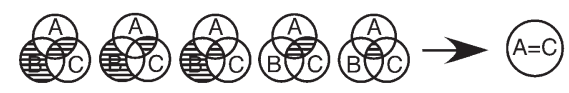

The following Venn diagrams are compatible with $A$ being a subset of $C$ :

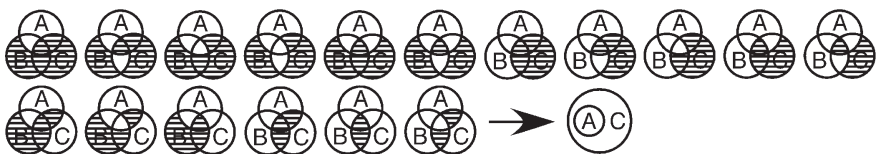

The following Venn diagrams are compatible with $\mathrm{A}$ being a superset of $\mathrm{C}$ :

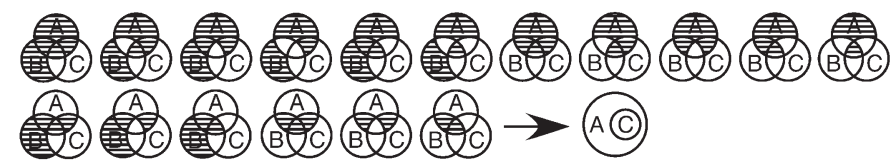

The following Venn diagrams are compatible with the exclusion relationship between $\mathrm{A}$ and $\mathrm{C}$ :

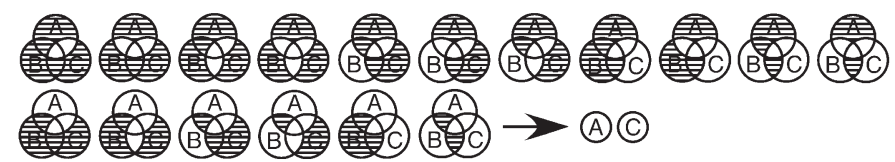

The following Venn diagrams are compatible with the intersection relationship between $A$ and $C$ :

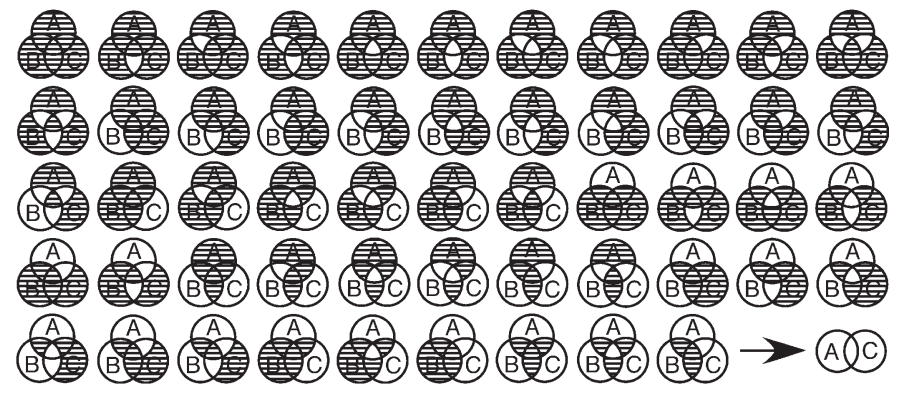

Figure A1. Venn diagrams denoting three sets (A, B, and C), categorized according to the outcome categories to which these are equivalent in linking $A$ and $C$. 
APPENDIXA (Continued)

Given the premise meanings shown in Table 1, we can apply a subtraction method for solving categorical syllogisms. Each premise specifies a relationship between two entities (A and B in the first premise, B and C in the second), which is compatible with some Venn diagrams and not with others. If we delete the incompatible diagrams for each premise, those that remain are the only ones that are compatible with both. From these, we can see which of the five relationships between $\mathrm{A}$ and $\mathrm{C}$ are likewise compatible with both premises. The latter will be named outcome categories and are depicted by Euler circles in Figure A1. An example of applying the subtraction process is given in Figure A2. Here, we can see that this yields just six Venn diagrams that are compatible with both premises, which in turn gives three different outcome categories and the conclusion some $C$ are not $A$ (see also Table 1). In contrast, Figure A3 shows a situation in which the premise pairs rule out insufficient Venn diagrams and, hence, outcome categories for there to be any valid conclusion linking $\mathrm{A}$ and $\mathrm{C}$.

None of the $A$ are $B$
All of the $B$ are $C$

Venn diagrams incompatible with "None of the A are B" are deleted thus:

Venn diagrams incompatible with "All of the B are C" are deleted thus:
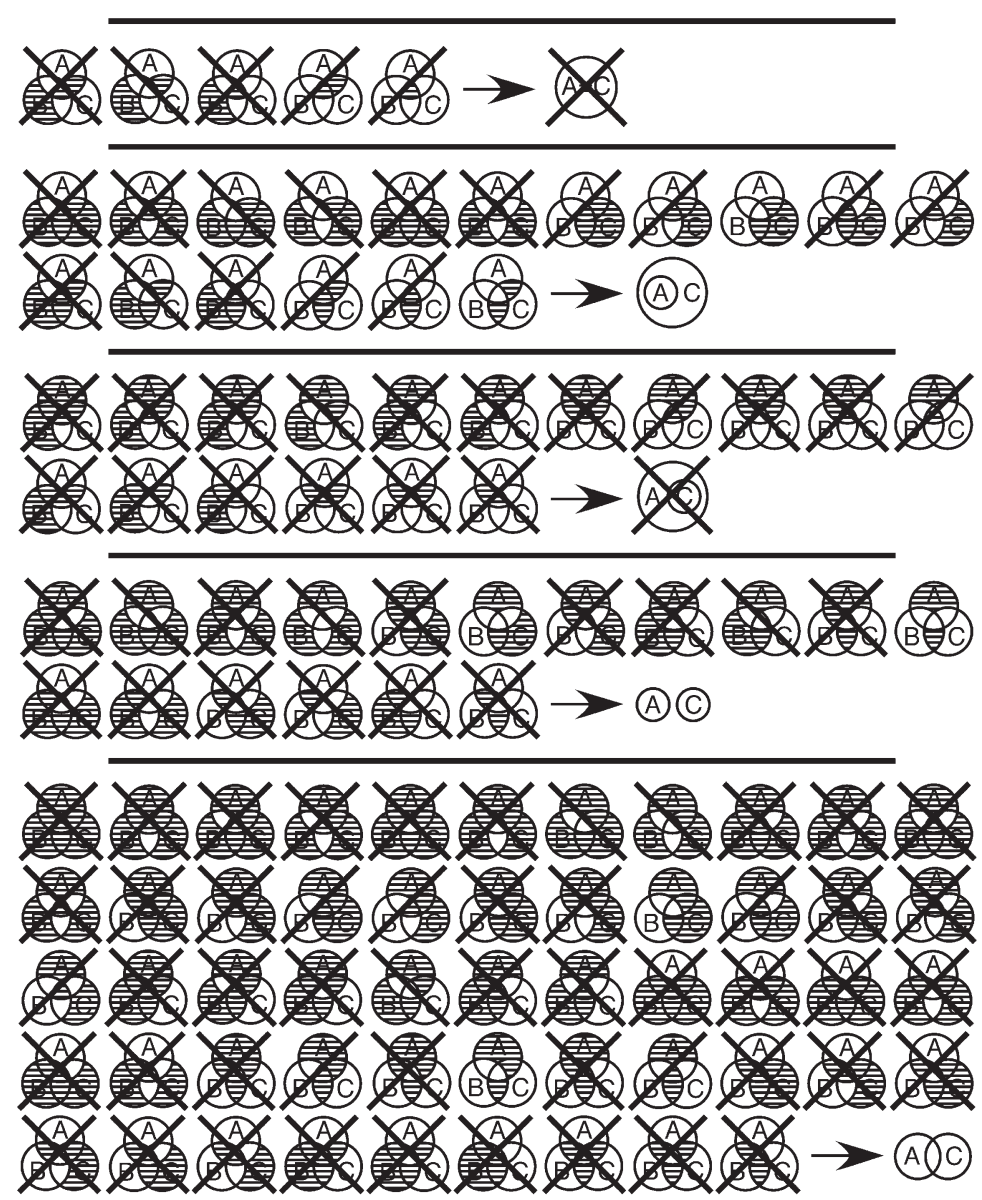

Figure A2. Venn diagrams that are incompatible with the premise pair $\mathrm{N}$ [aa]A[aa]4: $n o A$ are $B$ and all $B$ are $C$. No $A$ are $B$ rules out 92 Venn diagrams; all $B$ are $C$ rules out 87 . Only 6 diagrams are compatible with both premises, and the Euler circle relationships to which they correspond are compatible with only one valid conclusion: some $C$ are not $A$ (see Table 1). 
APPENDIXA (Continued)

Identifying the correct outcome categories and, hence, the correct answers depends on correct quantifier interpretations, as in Table 1 (see Roberts et al., 2001). For example, if we interpret all $A$ are $B$ to permit only the identity relationship (all $A$ are $B$ and all $B$ are $A$ ), this will reduce the number of compatible Venn diagrams, which subsequently might make one or more of the correct outcome categories unavailable, potentially leading to an incorrect conclusion.

Some of the $B$ are not $A$

Some of the $\mathrm{C}$ are $\mathrm{B}$

Venn diagrams incompatible with "Some of the B are not A" are deleted thus:

Venn diagrams incompatible with "Some of the $\mathrm{C}$ are B" are deleted thus:

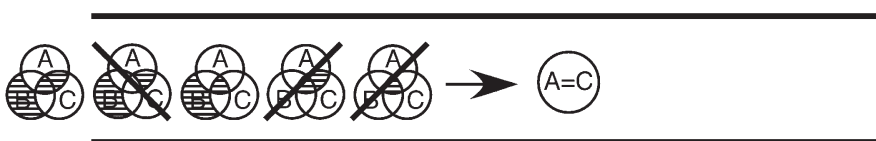

A A A $\mathrm{A}$ A A A A

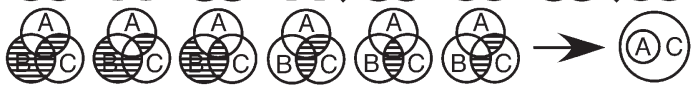

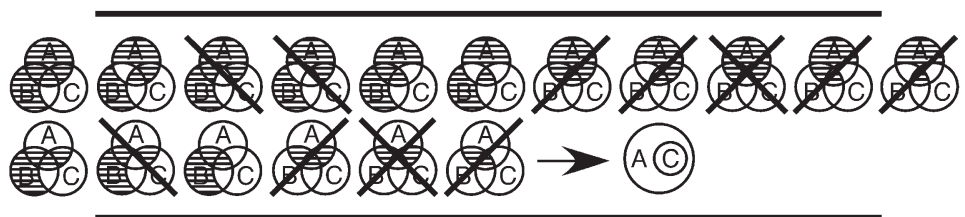

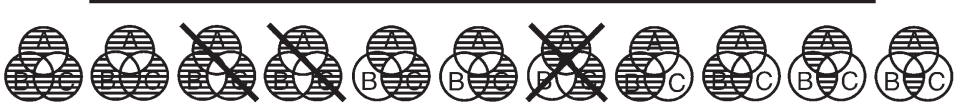
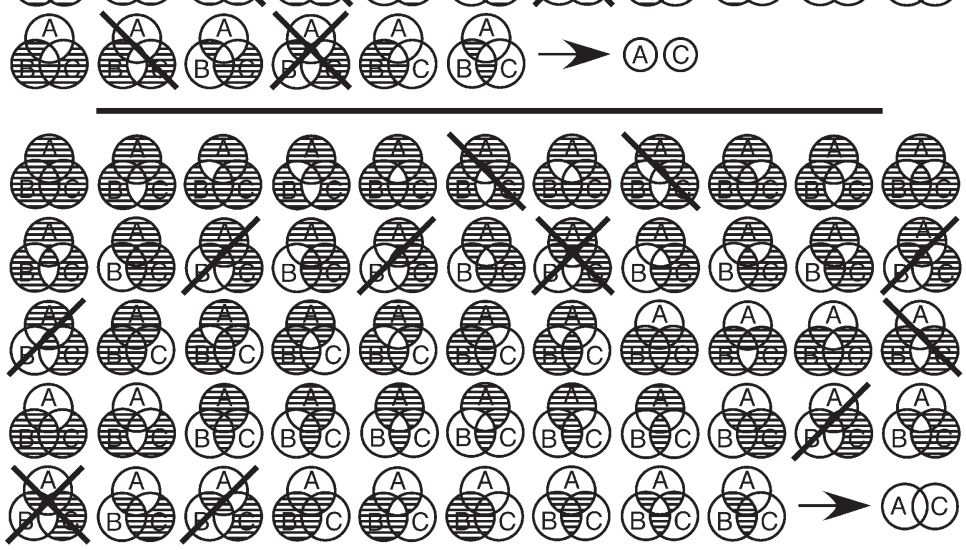

Figure A3. Venn diagrams that are incompatible with the premise pair S[an]S[aa]1: some $B$ are not $A$ and some $C$ are $B$. Some $C$ are $B$ rules out just 17 Venn diagrams; some $B$ are not $A$ rules out 22. Seventy-six diagrams are compatible with both premises, and none of the Euler circle relationships is ruled out. There is no valid conclusion describing the relationship between $A$ and $C$ (see Table 1). 
APPENDIXA (Continued)

When the 64 traditional premise pairs are considered, these yield seven different combinations of outcome categories (see Roberts \& Sykes, 2005). By taking into consideration the new quantifiers, these yield an additional seven combinations (see Appendices $\mathrm{C}-\mathrm{H}$ ). Figure A4 gives an example of one such item.

\section{All of the not-A are $B$}

All of the not- $\mathrm{C}$ are not-B

Venn diagrams incompatible with "All of the not-A are B" are deleted thus:

Venn diagrams incompatible with "All of the not-C are not-B" are deleted thus: 電寻
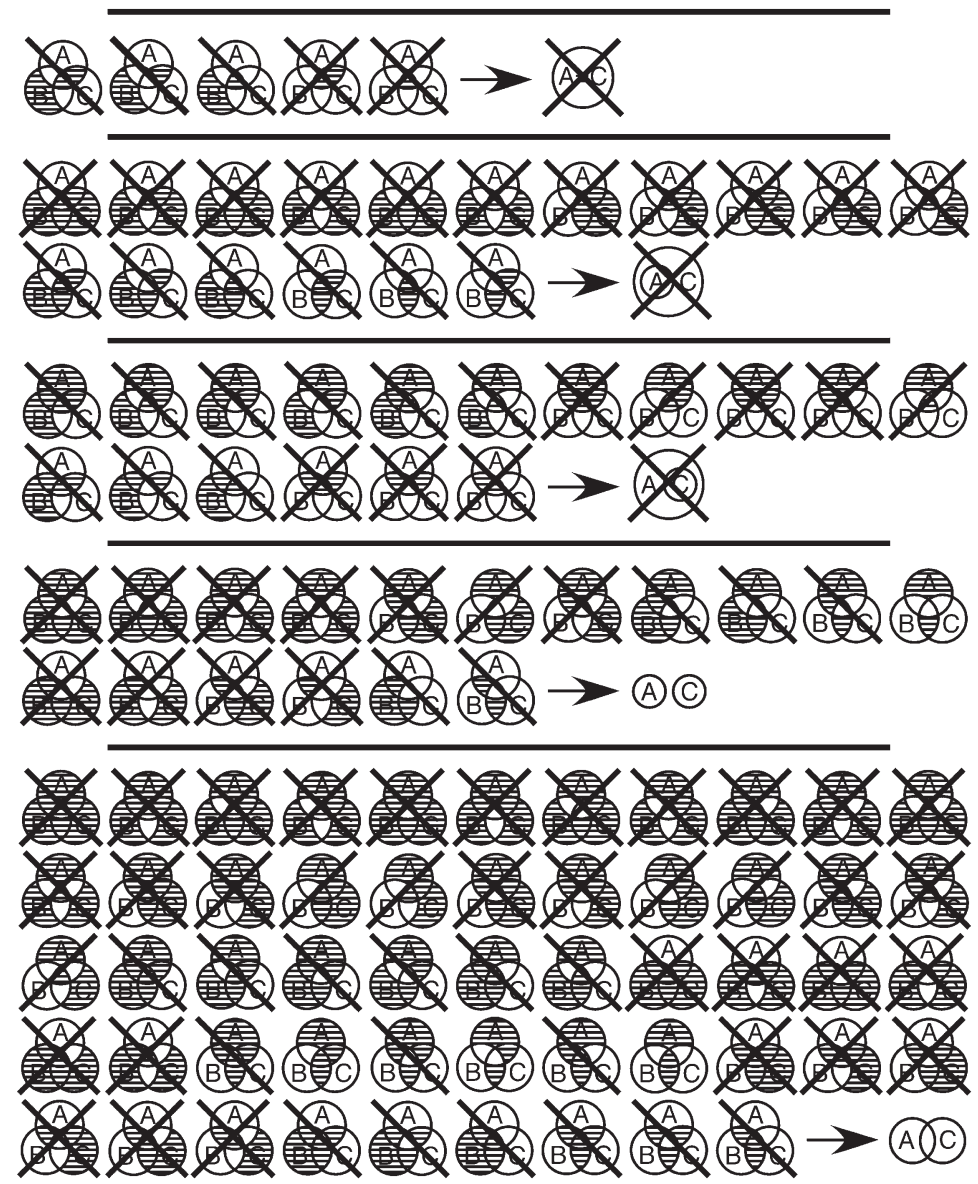

Figure A4. Venn diagrams that are incompatible with the premise pair $A[n a] A[n n] 2:$ all not- $A$ are $B$ and all not- $C$ are not- $B$. Assuming that instances of not-A, not-B, and not-C exist (as is implied by the premises), all not- $A$ are $B$ rules out 67 Venn diagrams, and all not-C are not-B rules out 97 . Only four diagrams are compatible with both premises, and the Euler circle relationships to which they correspond are compatible with the valid conclusions some $A$ are not $C$ and some $C$ are not $A$ (see Table 1). 


\section{APPENDIX B}

\section{Listing of Premise Pairs Along With Their Valid Conclusions}

Valid conclusions for premise pairs are given in Table B1. These are given in figure order (see Table 1) and, within this, alphabetically, using the new notation-hence, A (all) and S (some). N premises (no) always have an A premise equivalent, and so these are not included (see Table 2). Hence, for the premise pair N[aa]N[aa]1, the table entry for A[an]A[an]1 should be consulted. Lowercase letters in brackets denote combinations of negations. For example, a premise without negations is denoted [aa], a premise with a negated first but not second term is denoted [na], and so on. The 64 traditional premise pair equivalents are also highlighted. For example, $\mathrm{A}[\mathrm{aa}] \mathrm{A}[\mathrm{an}] 1$ is equivalent to $\mathrm{A}[\mathrm{aa}] \mathrm{N}[\mathrm{aa}] 1$ and, in this guise, is traditionally known as AE1: all $B$ are $A, n o C$ are $B$.

Not all valid conclusions are shown. Table 2 should be consulted to see whether equivalent conclusions with different permutations of negations are available. For example, if A[aa]CA is valid, so is N[an]CA. In addition, only the strongest valid conclusion is shown. For example, if A[aa]CA is valid, so is S[aa]CA, but this is not shown in Table B1 (see Table 2). Where valid conclusions with a negated first term are also available, these are denoted by an asterisk, and Appendices $\mathrm{C}-\mathrm{H}$ should be consulted for further details.

Table B1

Listing of All Combinations of Premise Pairs Along With Strongest Valid Conclusions

\begin{tabular}{|c|c|c|c|c|c|c|c|c|c|}
\hline \multicolumn{2}{|c|}{ Premise Pair/Notation } & \multirow{2}{*}{$\begin{array}{l}\text { Appendix } \\
\text { Entry }\end{array}$} & \multicolumn{2}{|c|}{$\begin{array}{l}\text { Valid Conclusions: } \\
\text { Standard Quantifiers }\end{array}$} & \multicolumn{2}{|c|}{ Premise Pair/Notation } & \multirow{2}{*}{$\begin{array}{l}\text { Appendix } \\
\text { Entry }\end{array}$} & \multicolumn{2}{|c|}{$\begin{array}{l}\text { Valid Conclusions: } \\
\text { Standard Quantifiers }\end{array}$} \\
\hline New & Old & & Direction $\mathrm{C}-\mathrm{A}$ & Direction $\mathrm{A}-\mathrm{C}$ & New & Old & & Direction $\mathrm{C}-\mathrm{A}$ & Direction A-C \\
\hline $\mathrm{A}[\mathrm{aa}] \mathrm{A}[\mathrm{aa}] 1$ & AA1 & $\mathrm{C} 1$ & $\mathrm{~A}[\mathrm{aa}]$ & $\mathrm{S}[\mathrm{aa}]$ & $\mathrm{S}[\mathrm{aa}] \mathrm{A}[\mathrm{aa}] 1$ & IA1 & $\mathrm{G}$ & NVC & NVC \\
\hline $\mathrm{A}[\mathrm{aa}] \mathrm{A}[\mathrm{an}] 1$ & AE1 & $\mathrm{F} 1$ & $\mathrm{NVC}^{*}$ & $\mathrm{~S}[\mathrm{an}]$ & $\mathrm{S}[\mathrm{aa}] \mathrm{A}[\mathrm{an}] 1$ & IE1 & F1 & $\mathrm{NVC}^{*}$ & $\mathrm{~S}[\mathrm{an}]$ \\
\hline $\mathrm{A}[\mathrm{aa}] \mathrm{A}[\mathrm{na}] 1$ & & $\mathrm{~F} 1$ & $\mathrm{NVC}^{*}$ & $\mathrm{~S}[\mathrm{an}]$ & $\mathrm{S}[\mathrm{aa}] \mathrm{A}[\mathrm{na}] 1$ & & $\mathrm{G}$ & NVC & NVC \\
\hline $\mathrm{A}[\mathrm{aa}] \mathrm{A}[\mathrm{nn}] 1$ & & E2 & $\mathrm{S}[\mathrm{aa}]^{*}$ & $\mathrm{~S}[\mathrm{aa}] \mathrm{S}[\mathrm{an}]$ & $\mathrm{S}[\mathrm{aa}] \mathrm{A}[\mathrm{nn}] 1$ & & E2 & $\mathrm{S}[\mathrm{aa}]^{*}$ & $\mathrm{~S}$ [aa] S[an] \\
\hline $\mathrm{A}[\mathrm{aa}] \mathrm{S}[\mathrm{aa}] 1$ & AI1 & E1 & $\mathrm{S}[\mathrm{aa}]$ & $\mathrm{S}[\mathrm{aa}]$ & $\mathrm{S}[\mathrm{aa}] \mathrm{S}[\mathrm{aa}] 1$ & II1 & $\mathrm{G}$ & NVC & NVC \\
\hline $\mathrm{A}[\mathrm{aa}] \mathrm{S}[\mathrm{an}] 1$ & $\mathrm{AO} 1$ & $\mathrm{G}$ & NVC & NVC & $\mathrm{S}[\mathrm{aa}] \mathrm{S}[\mathrm{an}] 1$ & IO1 & $\mathrm{G}$ & NVC & NVC \\
\hline $\mathrm{A}[\mathrm{aa}] \mathrm{S}[\mathrm{na}] 1$ & & F1 & $\mathrm{NVC}^{*}$ & $\mathrm{~S}[\mathrm{an}]$ & $\mathrm{S}[\mathrm{aa}] \mathrm{S}[\mathrm{na}] 1$ & & $\mathrm{G}$ & NVC & NVC \\
\hline $\mathrm{A}[\mathrm{aa}] \mathrm{S}[\mathrm{nn}] 1$ & & F1 & $\mathrm{NVC}^{*}$ & $\mathrm{~S}[\mathrm{an}]$ & $\mathrm{S}[\mathrm{aa}] \mathrm{S}[\mathrm{nn}] 1$ & & $\mathrm{~F} 1$ & $\mathrm{NVC}^{*}$ & $\mathrm{~S}[\mathrm{an}]$ \\
\hline $\mathrm{A}[\mathrm{an}] \mathrm{A}[\mathrm{aa}] 1$ & EA1 & $\mathrm{D}$ & $\mathrm{N}[\mathrm{aa}]^{*}$ & $\mathrm{~N}[\mathrm{aa}]^{*}$ & $\mathrm{~S}[\mathrm{an}] \mathrm{A}[\mathrm{aa}] 1$ & OA1 & G & NVC & NVC \\
\hline $\mathrm{A}[\mathrm{an}] \mathrm{A}[\mathrm{an}] 1$ & EE1 & $\mathrm{G}$ & $\mathrm{NVC}^{*}$ & $\mathrm{NVC}^{*}$ & S[an]A[an]1 & OE1 & $\mathrm{G}$ & $\mathrm{NVC}^{*}$ & $\mathrm{NVC}^{*}$ \\
\hline $\mathrm{A}[\mathrm{an}] \mathrm{A}[\mathrm{na}] 1$ & & $\mathrm{C} 3$ & $\mathrm{~S}[\mathrm{aa}]^{*}$ & $\mathrm{~A}[\mathrm{aa}]^{*}$ & $\mathrm{~S}[\mathrm{an}] \mathrm{A}[\mathrm{na}] 1$ & & $\mathrm{G}$ & NVC & NVC \\
\hline $\mathrm{A}[\mathrm{an}] \mathrm{A}[\mathrm{nn}] 1$ & & F3 & $\mathrm{S}[\mathrm{an}]^{*}$ & $\mathrm{~S}[\mathrm{an}]^{*}$ & $\mathrm{~S}[\mathrm{an}] \mathrm{A}[\mathrm{nn}] 1$ & & F3 & $\mathrm{S}[\mathrm{an}]^{*}$ & $\mathrm{~S}[\mathrm{an}]^{*}$ \\
\hline $\mathrm{A}[\mathrm{an}] \mathrm{S}[\mathrm{aa}] 1$ & EI1 & $\mathrm{F} 2$ & $\mathrm{~S}[\mathrm{an}]$ & $\mathrm{NVC}^{*}$ & $\mathrm{~S}$ [an]S[aa]1 & OI1 & $\mathrm{G}$ & NVC & NVC \\
\hline $\mathrm{A}[\mathrm{an}] \mathrm{S}[\mathrm{an}] 1$ & EO1 & $\mathrm{G}$ & NVC & NVC & $\mathrm{S}[\mathrm{an}] \mathrm{S}[\mathrm{an}] 1$ & OO1 & $\mathrm{G}$ & NVC & NVC \\
\hline A[an]S[na]1 & & $\mathrm{G}$ & $\mathrm{NVC}^{*}$ & $\mathrm{NVC}^{*}$ & $\mathrm{~S}[\mathrm{an}] \mathrm{S}[\mathrm{na}] 1$ & & $\mathrm{G}$ & NVC & NVC \\
\hline $\mathrm{A}[\mathrm{an}] \mathrm{S}[\mathrm{nn}] 1$ & & F1 & $\mathrm{NVC}^{*}$ & $\mathrm{~S}[\mathrm{an}]$ & $\mathrm{S}[\mathrm{an}] \mathrm{S}[\mathrm{nn}] 1$ & & F1 & $\mathrm{NVC}^{*}$ & $\mathrm{~S}[\mathrm{an}]$ \\
\hline $\mathrm{A}[\mathrm{na}] \mathrm{A}[\mathrm{aa}] 1$ & & $\mathrm{~F} 1$ & $\mathrm{NVC}^{*}$ & $\mathrm{~S}[\mathrm{an}]$ & $\mathrm{S}[\mathrm{na}] \mathrm{A}[\mathrm{aa}] 1$ & & $\mathrm{~F} 1$ & $\mathrm{NVC}^{*}$ & $\mathrm{~S}[\mathrm{an}]$ \\
\hline $\mathrm{A}[\mathrm{na}] \mathrm{A}[\mathrm{an}] 1$ & & $\mathrm{C} 1$ & $\mathrm{~A}[\mathrm{aa}]$ & $\mathrm{S}[\mathrm{aa}]$ & $\mathrm{S}[\mathrm{na}] \mathrm{A}[\mathrm{an}] 1$ & & $\mathrm{G}$ & NVC & NVC \\
\hline $\mathrm{A}[\mathrm{na}] \mathrm{A}[\mathrm{na}] 1$ & & E1 & $\mathrm{S}[\mathrm{aa}]$ & $\mathrm{S}[\mathrm{aa}]$ & S[na]A[na]1 & & E1 & $\mathrm{S}[\mathrm{aa}]$ & $\mathrm{S}[\mathrm{aa}]$ \\
\hline $\mathrm{A}[\mathrm{na}] \mathrm{A}[\mathrm{nn}] 1$ & & F1 & $\mathrm{NVC}^{*}$ & $\mathrm{~S}[\mathrm{an}]$ & $\mathrm{S}[\mathrm{na}] \mathrm{A}[\mathrm{nn}] 1$ & & F1 & $\mathrm{NVC}^{*}$ & $\mathrm{~S}[\mathrm{an}]$ \\
\hline A[na]S[aa]1 & & $\mathrm{G}$ & NVC & NVC & S[na]S[aa]1 & & $\mathrm{G}$ & NVC & NVC \\
\hline $\mathrm{A}[\mathrm{na}] \mathrm{S}[\mathrm{an}] 1$ & & E1 & $\mathrm{S}[\mathrm{aa}]$ & $\mathrm{S}[\mathrm{aa}]$ & S[na]S[an]1 & & $\mathrm{G}$ & NVC & NVC \\
\hline A[na]S[na]1 & & $\mathrm{G}$ & NVC & NVC & $\mathrm{S}[\mathrm{na} \mathrm{S}[\mathrm{na}] 1$ & & $\mathrm{G}$ & NVC & NVC \\
\hline $\mathrm{A}[\mathrm{na}] \mathrm{S}[\mathrm{nn}] 1$ & & F1 & $\mathrm{NVC}^{*}$ & $\mathrm{~S}[\mathrm{an}]$ & $\mathrm{S}[\mathrm{na}] \mathrm{S}[\mathrm{nn}] 1$ & & $\mathrm{~F} 1$ & $\mathrm{NVC}^{*}$ & $\mathrm{~S}[\mathrm{an}]$ \\
\hline $\mathrm{A}[\mathrm{nn}] \mathrm{A}[\mathrm{aa}] 1$ & & $\mathrm{H}$ & NVC & NVC & $\mathrm{S}[\mathrm{nn}] \mathrm{A}[\mathrm{aa}] 1$ & & $\mathrm{H}$ & NVC & NVC \\
\hline $\mathrm{A}[\mathrm{nn}] \mathrm{A}[\mathrm{an}] 1$ & & $\mathrm{D}$ & $\mathrm{N}[\mathrm{aa}]^{*}$ & $\mathrm{~N}[\mathrm{aa}]^{*}$ & $\mathrm{~S}[\mathrm{nn}] \mathrm{A}[\mathrm{an}] 1$ & & $\mathrm{~F} 2$ & $\mathrm{~S}[\mathrm{an}]$ & $\mathrm{NVC}^{*}$ \\
\hline $\mathrm{A}[\mathrm{nn}] \mathrm{A}[\mathrm{na}] 1$ & & $\mathrm{~F} 2$ & $\mathrm{~S}[\mathrm{an}]$ & $N^{*} C^{*}$ & $\mathrm{~S}[\mathrm{nn}] \mathrm{A}[\mathrm{na}] 1$ & & $\mathrm{~F} 2$ & $\mathrm{~S}[\mathrm{an}]$ & $\mathrm{NVC}^{*}$ \\
\hline $\mathrm{A}[\mathrm{nn}] \mathrm{A}[\mathrm{nn}] 1$ & & $\mathrm{H}$ & NVC & NVC & $\mathrm{S}[\mathrm{nn}] \mathrm{A}[\mathrm{nn}] 1$ & & F3 & $\mathrm{S}[\mathrm{an}]^{*}$ & $\mathrm{~S}[\mathrm{an}]^{*}$ \\
\hline A[nn]S[aa]1 & & $\mathrm{F} 2$ & $\mathrm{~S}[\mathrm{an}]$ & $\mathrm{NVC}^{*}$ & $\mathrm{~S}[\mathrm{nn}] \mathrm{S}[\mathrm{aa}] 1$ & & $\mathrm{~F} 2$ & $\mathrm{~S}[\mathrm{an}]$ & $\mathrm{NVC}^{*}$ \\
\hline $\mathrm{A}[\mathrm{nn}] \mathrm{S}[\mathrm{an}] 1$ & & $\mathrm{~F} 2$ & $\mathrm{~S}[\mathrm{an}]$ & $\mathrm{NVC}^{*}$ & $\mathrm{~S}[\mathrm{nn}] \mathrm{S}[\mathrm{an}] 1$ & & $\mathrm{~F} 2$ & $\mathrm{~S}[\mathrm{an}]$ & $\mathrm{NVC}^{*}$ \\
\hline $\mathrm{A}[\mathrm{nn}] \mathrm{S}[\mathrm{na}] 1$ & & $\mathrm{~F} 2$ & $\mathrm{~S}[\mathrm{an}]$ & $\mathrm{NVC}^{*}$ & $\mathrm{~S}[\mathrm{nn}] \mathrm{S}[\mathrm{na}] 1$ & & $\mathrm{~F} 2$ & $\mathrm{~S}[\mathrm{an}]$ & $\mathrm{NVC}^{*}$ \\
\hline $\mathrm{A}[\mathrm{nn}] \mathrm{S}[\mathrm{nn}] 1$ & & $\mathrm{H}$ & NVC & NVC & $\mathrm{S}[\mathrm{nn}] \mathrm{S}[\mathrm{nn}] 1$ & & F3 & $\mathrm{S}[\mathrm{an}]^{*}$ & $\mathrm{~S}[\mathrm{an}]^{*}$ \\
\hline $\mathrm{A}[\mathrm{aa}] \mathrm{A}[\mathrm{aa}] 2$ & AA2 & G & NVC & NVC & $\mathrm{S}[\mathrm{aa}] \mathrm{A}[\mathrm{aa}] 2$ & IA2 2 & $\mathrm{G}$ & NVC & NVC \\
\hline $\mathrm{A}[\mathrm{aa}] \mathrm{A}[\mathrm{an}] 2$ & AE2 & $\mathrm{D}$ & $\mathrm{N}[\mathrm{aa}]^{*}$ & $\mathrm{~N}[\mathrm{aa}]^{*}$ & $\mathrm{~S}[\mathrm{aa}] \mathrm{A}[\mathrm{an}] 2$ & IE2 & F1 & $\mathrm{NVC}^{*}$ & $\mathrm{~S}[\mathrm{an}]$ \\
\hline A[aa]A[na]2 & & $\mathrm{G}$ & NVC & NVC & $\mathrm{S}[\mathrm{aa}] \mathrm{A}[\mathrm{na}] 2$ & & $\mathrm{G}$ & NVC & NVC \\
\hline $\mathrm{A}[\mathrm{aa}] \mathrm{A}[\mathrm{nn}] 2$ & & $\mathrm{H}$ & NVC & NVC & $\mathrm{S}[\mathrm{aa}] \mathrm{A}[\mathrm{nn}] 2$ & & $\mathrm{E} 2$ & $\mathrm{~S}[\mathrm{aa}]^{*}$ & $\mathrm{~S}$ [aa] S[an] \\
\hline $\mathrm{A}[\mathrm{aa}] \mathrm{S}[\mathrm{aa}] 2$ & $\mathrm{AI} 2$ & $\mathrm{G}$ & NVC & NVC & $\mathrm{S}[\mathrm{aa}] \mathrm{S}[\mathrm{aa}] 2$ & $\mathrm{II} 2$ & $\mathrm{G}$ & NVC & NVC \\
\hline $\mathrm{A}[\mathrm{aa}] \mathrm{S}[\mathrm{an}] 2$ & $\mathrm{AO} 2$ & $\mathrm{~F} 2$ & $\mathrm{~S}[\mathrm{an}]$ & $\mathrm{NVC}^{*}$ & $\mathrm{~S}[\mathrm{aa}] \mathrm{S}[\mathrm{an}] 2$ & $\mathrm{IO} 2$ & $\mathrm{G}$ & NVC & NVC \\
\hline A[aa]S[na]2 & & $\mathrm{G}$ & NVC & NVC & $\mathrm{S}[\mathrm{aa}] \mathrm{S}[\mathrm{na}] 2$ & & G & NVC & NVC \\
\hline $\mathrm{A}[\mathrm{aa}] \mathrm{S}[\mathrm{nn}] 2$ & & $\mathrm{H}$ & NVC & NVC & $\mathrm{S}[\mathrm{aa}] \mathrm{S}[\mathrm{nn}] 2$ & & $\mathrm{~F} 1$ & $\mathrm{NVC}^{*}$ & $\mathrm{~S}[\mathrm{an}]$ \\
\hline
\end{tabular}


APPENDIX B (Continued)

\begin{tabular}{|c|c|c|c|c|c|c|c|c|c|}
\hline \multicolumn{2}{|c|}{ Premise Pair/Notation } & \multirow{2}{*}{$\begin{array}{l}\text { Appendix } \\
\text { Entry }\end{array}$} & \multicolumn{2}{|c|}{$\begin{array}{l}\text { Valid Conclusions: } \\
\text { Standard Quantifiers }\end{array}$} & \multicolumn{2}{|c|}{ Premise Pair/Notation } & \multirow{2}{*}{$\begin{array}{l}\text { Appendix } \\
\text { Entry }\end{array}$} & \multicolumn{2}{|c|}{$\begin{array}{l}\text { Valid Conclusions: } \\
\text { Standard Quantifiers }\end{array}$} \\
\hline New & Old & & Direction $\mathrm{C}-\mathrm{A}$ & Direction A-C & New & Old & & Direction $\mathrm{C}-\mathrm{A}$ & Direction A-C \\
\hline $\mathrm{A}[\mathrm{an}] \mathrm{A}[\mathrm{aa}] 2$ & EA2 & $\mathrm{D}$ & $\mathrm{N}[\mathrm{aa}]^{*}$ & $\mathrm{~N}[\mathrm{aa}]^{*}$ & $\mathrm{~S}[\mathrm{an}] \mathrm{A}[\mathrm{aa}] 2$ & OA2 & F1 & $\mathrm{NVC}^{*}$ & $\mathrm{~S}[\mathrm{an}]$ \\
\hline $\mathrm{A}[\mathrm{an}] \mathrm{A}[\mathrm{an}] 2$ & EE2 & $\mathrm{G}$ & $\mathrm{NVC}^{*}$ & $\mathrm{NVC}^{*}$ & $\mathrm{~S}[\mathrm{an}] \mathrm{A}[\mathrm{an}] 2$ & OE2 & $\mathrm{G}$ & NVC & NVC \\
\hline A[an]A[na]2 & & $\mathrm{C} 3$ & $\mathrm{~S}[\mathrm{aa}]^{*}$ & $\mathrm{~A}[\mathrm{aa}]^{*}$ & $\mathrm{~S}[\mathrm{an}] \mathrm{A}[\mathrm{na}] 2$ & & E1 & $\mathrm{S}[\mathrm{a}]$ & $\mathrm{S}[\mathrm{aa}]$ \\
\hline $\mathrm{A}[\mathrm{an}] \mathrm{A}[\mathrm{nn}] 2$ & & F3 & $\mathrm{S}[\mathrm{an}]^{*}$ & $\mathrm{~S}[\mathrm{an}]^{*}$ & $\mathrm{~S}[\mathrm{an}] \mathrm{A}[\mathrm{nn}] 2$ & & $\mathrm{~F} 1$ & $\mathrm{NVC}^{*}$ & $\mathrm{~S}[\mathrm{an}]$ \\
\hline $\mathrm{A}[\mathrm{an}] \mathrm{S}[\mathrm{aa}] 2$ & EI2 & $\mathrm{F} 2$ & $\mathrm{~S}[\mathrm{an}]$ & $\mathrm{NVC}^{*}$ & $\mathrm{~S}[\mathrm{an}] \mathrm{S}[\mathrm{aa}] 2$ & OI2 & G & NVC & NVC \\
\hline $\mathrm{A}[\mathrm{an}] \mathrm{S}[\mathrm{an}] 2$ & $\mathrm{EO} 2$ & $\mathrm{G}$ & NVC & NVC & $\mathrm{S}[\mathrm{an}] \mathrm{S}[\mathrm{an}] 2$ & $\mathrm{OO} 2$ & G & NVC & NVC \\
\hline $\mathrm{A}[\mathrm{an}] \mathrm{S}[\mathrm{na} 2$ & & $\mathrm{G}$ & $\mathrm{NVC}^{*}$ & $\mathrm{NVC}^{*}$ & $\mathrm{~S}[\mathrm{an}] \mathrm{S}[\mathrm{na}] 2$ & & $\mathrm{G}$ & NVC & NVC \\
\hline $\mathrm{A}[\mathrm{an}] \mathrm{S}[\mathrm{nn}] 2$ & & $\mathrm{~F} 1$ & $\mathrm{NVC}^{*}$ & $\mathrm{~S}[\mathrm{an}]$ & $\mathrm{S}[\mathrm{an}] \mathrm{S}[\mathrm{nn}] 2$ & & $\mathrm{~F} 1$ & $\mathrm{NVC}^{*}$ & $\mathrm{~S}[\mathrm{an}]$ \\
\hline $\mathrm{A}[\mathrm{na}] \mathrm{A}[\mathrm{aa}] 2$ & & G & NVC & NVC & $\mathrm{S}[\mathrm{na}] \mathrm{A}[\mathrm{aa}] 2$ & & G & NVC & NVC \\
\hline A[na]A[an]2 & & $\mathrm{C} 1$ & $\mathrm{~A}[\mathrm{aa}]^{*}$ & $\mathrm{~S}[\mathrm{aa}]^{*}$ & $\mathrm{~S}[\mathrm{na}] \mathrm{A}[\mathrm{an}] 2$ & & G & $\mathrm{NVC}^{*}$ & $\mathrm{NVC}^{*}$ \\
\hline A[na]A[na]2 & & $\mathrm{G}$ & NVC & NVC & S[na]A[na]2 & & $\mathrm{G}$ & NVC & NVC \\
\hline $\mathrm{A}[\mathrm{na}] \mathrm{A}[\mathrm{nn}] 2$ & & F3 & $\mathrm{S}[\mathrm{an}]^{*}$ & $\mathrm{~S}[\mathrm{an}]^{*}$ & $\mathrm{~S}[\mathrm{na}] \mathrm{A}[\mathrm{nn}] 2$ & & $\mathrm{~F} 3$ & $\mathrm{~S}[\mathrm{an}]^{*}$ & $\mathrm{~S}[\mathrm{an}]^{*}$ \\
\hline $\mathrm{A}[\mathrm{na}] \mathrm{S}[\mathrm{aa}] 2$ & & $\mathrm{G}$ & NVC & NVC & $\mathrm{S}[\mathrm{na}] \mathrm{S}[\mathrm{aa}] 2$ & & G & NVC & NVC \\
\hline A[na]S[an]2 & & E1 & $\mathrm{S}[\mathrm{aa}]$ & $\mathrm{S}[\mathrm{aa}]$ & $\mathrm{S}[\mathrm{na}] \mathrm{S}[\mathrm{an}] 2$ & & $\mathrm{G}$ & NVC & NVC \\
\hline A[na]S[na]2 & & G & NVC & NVC & S[na]S[na]2 & & G & NVC & NVC \\
\hline $\mathrm{A}[\mathrm{na}] \mathrm{S}[\mathrm{nn}] 2$ & & $\mathrm{~F} 1$ & $\mathrm{NVC}^{*}$ & $\mathrm{~S}[\mathrm{an}]$ & $\mathrm{S}[\mathrm{na}] \mathrm{S}[\mathrm{nn}] 2$ & & $\mathrm{~F} 1$ & $\mathrm{NVC}^{*}$ & $\mathrm{~S}[\mathrm{an}]$ \\
\hline $\mathrm{A}[\mathrm{nn}] \mathrm{A}[\mathrm{aa}] 2$ & & $\mathrm{H}$ & NVC & NVC & $\mathrm{S}[\mathrm{nn}] \mathrm{A}[\mathrm{aa}] 2$ & & $\mathrm{H}$ & NVC & NVC \\
\hline $\mathrm{A}[\mathrm{nn}] \mathrm{A}[\mathrm{an}] 2$ & & F3 & $\mathrm{S}[\mathrm{an}]^{*}$ & $\mathrm{~S}[\mathrm{an}]^{*}$ & $\mathrm{~S}[\mathrm{nn}] \mathrm{A}[\mathrm{an}] 2$ & & $\mathrm{~F} 2$ & $\mathrm{~S}[\mathrm{an}]$ & $\mathrm{NVC}^{*}$ \\
\hline $\mathrm{A}[\mathrm{nn}] \mathrm{A}[\mathrm{na}] 2$ & & F3 & $\mathrm{S}[\mathrm{an}]^{*}$ & $\mathrm{~S}[\mathrm{an}]^{*}$ & $\mathrm{~S}[\mathrm{nn}] \mathrm{A}[\mathrm{na}] 2$ & & $\mathrm{~F} 2$ & $\mathrm{~S}[\mathrm{an}]$ & $\mathrm{NVC}^{*}$ \\
\hline $\mathrm{A}[\mathrm{nn}] \mathrm{A}[\mathrm{nn}] 2$ & & E4 & $\mathrm{S}[\mathrm{aa}] \mathrm{S}[\mathrm{an}]^{*}$ & $\mathrm{~S}[\mathrm{aa}] \mathrm{S}[\mathrm{an}]^{*}$ & $\mathrm{~S}[\mathrm{nn}] \mathrm{A}[\mathrm{nn}] 2$ & & $\mathrm{~F} 3$ & $\mathrm{~S}[\mathrm{an}]^{*}$ & $\mathrm{~S}[\mathrm{an}]^{*}$ \\
\hline $\mathrm{A}[\mathrm{nn}] \mathrm{S}[\mathrm{aa}] 2$ & & E3 & $\mathrm{S}[\mathrm{aa}] \mathrm{S}[\mathrm{an}]$ & $\mathrm{S}[\mathrm{aa}]^{*}$ & $\mathrm{~S}[\mathrm{nn}] \mathrm{S}[\mathrm{aa}] 2$ & & $\mathrm{~F} 2$ & S[an] & $\mathrm{NVC}^{*}$ \\
\hline $\mathrm{A}[\mathrm{nn}] \mathrm{S}[\mathrm{an}] 2$ & & $\mathrm{~F} 2$ & $\mathrm{~S}[\mathrm{an}]$ & $\mathrm{NVC}^{*}$ & $\mathrm{~S}[\mathrm{nn}] \mathrm{S}[\mathrm{an}] 2$ & & F2 & S[an] & $\mathrm{NVC}^{*}$ \\
\hline $\mathrm{A}[\mathrm{nn}] \mathrm{S}[\mathrm{na}] 2$ & & F3 & S[an]* & $\mathrm{S}[\mathrm{an}]^{*}$ & $\mathrm{~S}[\mathrm{nn}] \mathrm{S}[\mathrm{na}] 2$ & & $\mathrm{~F} 2$ & $\mathrm{~S}[\mathrm{an}]$ & $\mathrm{NVC}^{*}$ \\
\hline $\mathrm{A}[\mathrm{nn}] \mathrm{S}[\mathrm{nn}] 2$ & & F3 & $\mathrm{S}[\mathrm{an}]^{*}$ & $\mathrm{~S}[\mathrm{an}]^{*}$ & $\mathrm{~S}[\mathrm{nn}] \mathrm{S}[\mathrm{nn}] 2$ & & F3 & $\mathrm{S}[\mathrm{an}]^{*}$ & $\mathrm{~S}[\mathrm{an}]^{*}$ \\
\hline $\mathrm{A}[\mathrm{aa}] \mathrm{A}[\mathrm{aa}] 3$ & AA3 & E1 & $\mathrm{S}[\mathrm{aa}]$ & $\mathrm{S}[\mathrm{aa}]$ & $\mathrm{S}[\mathrm{aa}] \mathrm{A}[\mathrm{aa}] 3$ & IA3 & E1 & $\mathrm{S}[\mathrm{aa}]$ & $\mathrm{S}[\mathrm{aa}]$ \\
\hline A[aa]A[an]3 & AE3 & $\mathrm{F} 1$ & $\mathrm{NVC}^{*}$ & $\mathrm{~S}[\mathrm{an}]$ & $\mathrm{S}[\mathrm{a} a] \mathrm{A}[\mathrm{an}] 3$ & IE3 & F1 & $\mathrm{NVC}^{*}$ & $\mathrm{~S}[\mathrm{an}]$ \\
\hline $\mathrm{A}[\mathrm{aa}] \mathrm{A}[\mathrm{na}] 3$ & & $\mathrm{G}$ & NVC & NVC & S[aa]A[na]3 & & $\mathrm{G}$ & NVC & NVC \\
\hline $\mathrm{A}[\mathrm{aa}] \mathrm{A}[\mathrm{nn}] 3$ & & $\mathrm{C} 2$ & $\mathrm{~A}[\mathrm{aa}]^{*}$ & $\mathrm{~S}[\mathrm{aa}] \mathrm{S}[\mathrm{an}]$ & $\mathrm{S}[\mathrm{aa}] \mathrm{A}[\mathrm{nn}] 3$ & & $\mathrm{~F} 1$ & $\mathrm{NVC}^{*}$ & $\mathrm{~S}[\mathrm{an}]$ \\
\hline $\mathrm{A}[\mathrm{aa}] \mathrm{S}[\mathrm{aa}] 3$ & $\mathrm{AI} 3$ & E1 & $\mathrm{S}[\mathrm{aa}]$ & $\mathrm{S}[\mathrm{aa}]$ & $\mathrm{S}[\mathrm{aa}] \mathrm{S}[\mathrm{aa}] 3$ & II3 & $\mathrm{G}$ & NVC & NVC \\
\hline A[aa]S[an]3 & $\mathrm{AO} 3$ & $\mathrm{~F} 1$ & NVC $^{*}$ & $\mathrm{~S}[\mathrm{an}]$ & $\mathrm{S}[\mathrm{aa}] \mathrm{S}[\mathrm{an}] 3$ & IO3 & G & NVC & NVC \\
\hline $\mathrm{A}[\mathrm{aa}] \mathrm{S}[\mathrm{na}] 3$ & & $\mathrm{G}$ & NVC & NVC & $\mathrm{S}[\mathrm{aa}] \mathrm{S}[\mathrm{na}] 3$ & & G & NVC & $\mathrm{NVC}$ \\
\hline $\mathrm{A}[\mathrm{aa}] \mathrm{S}[\mathrm{nn}] 3$ & & F1 & $\mathrm{NVC}^{*}$ & $\mathrm{~S}[\mathrm{an}]$ & $\mathrm{S}[\mathrm{aa}] \mathrm{S}[\mathrm{nn}] 3$ & & $\mathrm{~F} 1$ & $\mathrm{NVC}^{*}$ & $\mathrm{~S}[\mathrm{an}]$ \\
\hline $\mathrm{A}[\mathrm{an}] \mathrm{A}[\mathrm{aa}] 3$ & EA3 & $\mathrm{F} 2$ & $\mathrm{~S}[\mathrm{an}]$ & $\mathrm{NVC}^{*}$ & $\mathrm{~S}[\mathrm{an}] \mathrm{A}[\mathrm{aa}] 3$ & OA3 & F2 & $\mathrm{S}[\mathrm{an}]$ & $\mathrm{NVC}^{*}$ \\
\hline $\mathrm{A}[\mathrm{an}] \mathrm{A}[\mathrm{an}] 3$ & EE3 & $\mathrm{G}$ & $\mathrm{NVC}^{*}$ & $\mathrm{NVC}^{*}$ & $\mathrm{~S}[\mathrm{an}] \mathrm{A}[\mathrm{an}] 3$ & OE3 & $\mathrm{G}$ & $\mathrm{NVC}^{*}$ & $\mathrm{NVC}^{*}$ \\
\hline $\mathrm{A}[\mathrm{an}] \mathrm{A}[\mathrm{na}] 3$ & & $\mathrm{C} 3$ & $\mathrm{~S}[\mathrm{aa}]$ & $\mathrm{A}[\mathrm{aa}]$ & $\mathrm{S}[\mathrm{an}] \mathrm{A}[\mathrm{na}] 3$ & & $\mathrm{G}$ & NVC & NVC \\
\hline A[an]A[nn]3 & & $\mathrm{D}$ & $\mathrm{N}[\mathrm{aa}]^{*}$ & $\mathrm{~N}[\mathrm{aa}]^{*}$ & $\mathrm{~S}[\mathrm{an}] \mathrm{A}[\mathrm{nn}] 3$ & & $\mathrm{~F} 1$ & $\mathrm{NVC}^{*}$ & $\mathrm{~S}[\mathrm{an}]$ \\
\hline $\mathrm{A}[\mathrm{an}] \mathrm{S}[\mathrm{aa}] 3$ & EI3 & F2 & $\mathrm{S}[\mathrm{an}]$ & $\mathrm{NVC}^{*}$ & $\mathrm{~S}[\mathrm{an}] \mathrm{S}[\mathrm{aa}] 3$ & OI3 & G & NVC & NVC \\
\hline $\mathrm{A}[\mathrm{an}] \mathrm{S}[\mathrm{an}] 3$ & $\mathrm{EO} 3$ & $\mathrm{G}$ & NVC $^{*}$ & $\mathrm{NVC}^{*}$ & $\mathrm{~S}[\mathrm{an}] \mathrm{S}[\mathrm{an}] 3$ & OO3 & $\mathrm{G}$ & NVC & NVC \\
\hline $\mathrm{A}[\mathrm{an}] \mathrm{S}[\mathrm{na}] 3$ & & $\mathrm{G}$ & NVC & NVC & $\mathrm{S}[\mathrm{an}] \mathrm{S}[\mathrm{na}] 3$ & & G & NVC & NVC \\
\hline $\mathrm{A}[\mathrm{an}] \mathrm{S}[\mathrm{nn}] 3$ & & $\mathrm{~F} 1$ & $\mathrm{NVC}^{*}$ & $\mathrm{~S}[\mathrm{an}]$ & $\mathrm{S}[\mathrm{an}] \mathrm{S}[\mathrm{nn}] 3$ & & $\mathrm{~F} 1$ & $\mathrm{NVC}^{*}$ & $\mathrm{~S}[\mathrm{an}]$ \\
\hline $\mathrm{A}[\mathrm{na}] \mathrm{A}[\mathrm{aa}] 3$ & & G & NVC & NVC & $\mathrm{S}[\mathrm{na}] \mathrm{A}[\mathrm{aa}] 3$ & & $\mathrm{G}$ & NVC & NVC \\
\hline A[na]A[an]3 & & $\mathrm{C} 1$ & $\mathrm{~A}[\mathrm{aa}]$ & $\mathrm{S}[\mathrm{aa}]$ & $\mathrm{S}[\mathrm{n}$ ] $\mathrm{A}[\mathrm{an}] 3$ & & G & NVC & NVC \\
\hline $\mathrm{A}[\mathrm{na}] \mathrm{A}[\mathrm{na}] 3$ & & E1 & $\mathrm{S}[\mathrm{aa}]$ & $\mathrm{S}[\mathrm{aa}]$ & $\mathrm{S}[\mathrm{na}] \mathrm{A}[\mathrm{na}] 3$ & & E1 & $\mathrm{S}[\mathrm{aa}]$ & $\mathrm{S}[\mathrm{aa}]$ \\
\hline A[na]A[nn]3 & & $\mathrm{F} 1$ & $\mathrm{NVC}^{*}$ & $\mathrm{~S}[\mathrm{an}]$ & S[na]A[nn]3 & & $\mathrm{F} 1$ & $\mathrm{NVC}^{*}$ & S[an] \\
\hline $\mathrm{A}[\mathrm{na}] \mathrm{S}[\mathrm{aa}] 3$ & & $\mathrm{G}$ & NVC & NVC & $\mathrm{S}[\mathrm{na}] \mathrm{S}[\mathrm{aa}] 3$ & & $\mathrm{G}$ & NVC & NVC \\
\hline $\mathrm{A}[\mathrm{na}] \mathrm{S}[\mathrm{an}] 3$ & & $\mathrm{G}$ & NVC & NVC & S[na]S[an] 3 & & $\mathrm{G}$ & NVC & NVC \\
\hline A[na]S[na]3 & & E1 & $\mathrm{S}[\mathrm{aa}]$ & $\mathrm{S}[\mathrm{aa}]$ & $\mathrm{S}[\mathrm{na}] \mathrm{S}[\mathrm{na}] 3$ & & G & NVC & NVC \\
\hline $\mathrm{A}[\mathrm{na}] \mathrm{S}[\mathrm{nn}] 3$ & & $\mathrm{~F} 1$ & NVC $^{*}$ & $\mathrm{~S}[\mathrm{an}]$ & $\mathrm{S}[\mathrm{na}] \mathrm{S}[\mathrm{nn}] 3$ & & F1 & $\mathrm{NVC}^{*}$ & S[an] \\
\hline $\mathrm{A}[\mathrm{nn}] \mathrm{A}[\mathrm{aa}] 3$ & & $\mathrm{C} 4$ & $\mathrm{~S}[\mathrm{aa}] \mathrm{S}[\mathrm{an}]$ & $\mathrm{A}[\mathrm{aa}]^{*}$ & $\mathrm{~S}[\mathrm{nn}] \mathrm{A}[\mathrm{aa}] 3$ & & $\mathrm{~F} 2$ & $\mathrm{~S}[\mathrm{an}]$ & $\mathrm{NVC}^{*}$ \\
\hline $\mathrm{A}[\mathrm{nn}] \mathrm{A}[\mathrm{an}] 3$ & & $\mathrm{D}$ & $\mathrm{N}[\mathrm{aa}]^{*}$ & $\mathrm{~N}[\mathrm{aa}]^{*}$ & $\mathrm{~S}[\mathrm{nn}] \mathrm{A}[\mathrm{an}] 3$ & & $\mathrm{~F} 2$ & $\mathrm{~S}[\mathrm{an}]$ & $\mathrm{NVC}^{*}$ \\
\hline $\mathrm{A}[\mathrm{nn}] \mathrm{A}[\mathrm{na}] 3$ & & $\mathrm{~F} 2$ & $\mathrm{~S}[\mathrm{an}]$ & $\mathrm{NVC}^{*}$ & $\mathrm{~S}[\mathrm{nn}] \mathrm{A}[\mathrm{na}] 3$ & & $\mathrm{~F} 2$ & $\mathrm{~S}[\mathrm{an}]$ & $\mathrm{NVC}^{*}$ \\
\hline $\mathrm{A}[\mathrm{nn}] \mathrm{A}[\mathrm{nn}] 3$ & & $\mathrm{H}$ & NVC & NVC & S[nn]A[nn]3 & & $\mathrm{H}$ & NVC & NVC \\
\hline A[nn]S[aa] 3 & & F2 & $\mathrm{S}[\mathrm{an}]$ & $\mathrm{NVC}^{*}$ & $\mathrm{~S}[\mathrm{nn}] \mathrm{S}[\mathrm{aa}] 3$ & & $\mathrm{~F} 2$ & $\mathrm{~S}[\mathrm{an}]$ & $\mathrm{NVC}^{*}$ \\
\hline $\mathrm{A}[\mathrm{nn}] \mathrm{S}[\mathrm{an}] 3$ & & $\mathrm{~F} 2$ & $\mathrm{~S}[\mathrm{an}]$ & $\mathrm{NVC}^{*}$ & $\mathrm{~S}[\mathrm{nn}] \mathrm{S}[\mathrm{an}] 3$ & & $\mathrm{~F} 2$ & $\mathrm{~S}[\mathrm{an}]$ & $\mathrm{NVC}^{*}$ \\
\hline A[nn]S[na]3 & & F2 & $\mathrm{S}[\mathrm{an}]$ & $\mathrm{NVC}^{*}$ & $\mathrm{~S}[\mathrm{nn}] \mathrm{S}[\mathrm{na}] 3$ & & $\mathrm{~F} 2$ & $\mathrm{~S}[\mathrm{an}]$ & $\mathrm{NVC}^{*}$ \\
\hline $\mathrm{A}[\mathrm{nn}] \mathrm{S}[\mathrm{nn}] 3$ & & $\mathrm{H}$ & NVC & NVC & $\mathrm{S}[\mathrm{nn}] \mathrm{S}[\mathrm{nn}] 3$ & & F3 & $\mathrm{S}[\mathrm{an}]^{*}$ & $\mathrm{~S}[\mathrm{an}]^{*}$ \\
\hline
\end{tabular}


APPENDIX B (Continued)

\begin{tabular}{|c|c|c|c|c|c|c|c|c|c|}
\hline \multicolumn{10}{|c|}{ Table B1 (Continued) } \\
\hline \multicolumn{2}{|c|}{ Premise Pair/Notation } & \multirow{2}{*}{$\begin{array}{l}\text { Appendix } \\
\text { Entry }\end{array}$} & \multicolumn{2}{|c|}{$\begin{array}{l}\text { Valid Conclusions: } \\
\text { Standard Quantifiers }\end{array}$} & \multicolumn{2}{|c|}{ Premise Pair/Notation } & \multirow{2}{*}{$\begin{array}{l}\text { Appendix } \\
\text { Entry }\end{array}$} & \multicolumn{2}{|c|}{$\begin{array}{l}\text { Valid Conclusions: } \\
\text { Standard Quantifiers }\end{array}$} \\
\hline New & Old & & Direction $\mathrm{C}-\mathrm{A}$ & Direction A-C & New & Old & & Direction $\mathrm{C}-\mathrm{A}$ & Direction A-C \\
\hline $\mathrm{A}[\mathrm{aa}] \mathrm{A}[\mathrm{aa}] 4$ & AA4 & $\mathrm{C} 3$ & $\mathrm{~S}[\mathrm{aa}]$ & $\mathrm{A}[\mathrm{aa}]$ & $\mathrm{S}[\mathrm{aa}] \mathrm{A}[\mathrm{aa}] 4$ & IA4 & E1 & $\mathrm{S}[\mathrm{aa}]$ & $\mathrm{S}[\mathrm{aa}]$ \\
\hline $\mathrm{A}[\mathrm{aa}] \mathrm{A}[\mathrm{an}] 4$ & AE4 & $\mathrm{D}$ & $\mathrm{N}[\mathrm{aa}]^{*}$ & $\mathrm{~N}[\mathrm{aa}]^{*}$ & $\mathrm{~S}[\mathrm{aa}] \mathrm{A}[\mathrm{an}] 4$ & IE4 & F1 & $\mathrm{NVC}^{*}$ & $\mathrm{~S}[\mathrm{an}]$ \\
\hline $\mathrm{A}[\mathrm{a}] \mathrm{A}[\mathrm{na}] 4$ & & F2 & $\mathrm{S}[\mathrm{an}]$ & $\mathrm{NVC}^{*}$ & $\mathrm{~S}[\mathrm{aa}] \mathrm{A}[\mathrm{na}] 4$ & & $\mathrm{G}$ & NVC & NVC \\
\hline $\mathrm{A}[\mathrm{aa}] \mathrm{A}[\mathrm{nn}] 4$ & & $\mathrm{H}$ & NVC & NVC & $\mathrm{S}[\mathrm{aa}] \mathrm{A}[\mathrm{nn}] 4$ & & F1 & $\mathrm{NVC}^{*}$ & $\mathrm{~S}[\mathrm{an}]$ \\
\hline $\mathrm{A}[\mathrm{aa}] \mathrm{S}[\mathrm{aa}] 4$ & AI4 & $\mathrm{G}$ & NVC & NVC & $\mathrm{S}[\mathrm{aa}] \mathrm{S}[\mathrm{aa}] 4$ & II4 & $\mathrm{G}$ & NVC & NVC \\
\hline $\mathrm{A}[\mathrm{aa}] \mathrm{S}[\mathrm{an}] 4$ & $\mathrm{AO} 4$ & $\mathrm{G}$ & $\mathrm{NVC}$ & $\mathrm{NVC}$ & $\mathrm{S}[\mathrm{a} a] \mathrm{S}[\mathrm{an}] 4$ & IO4 & G & $\mathrm{NVC}$ & NVC \\
\hline $\mathrm{A}[\mathrm{aa}] \mathrm{S}[\mathrm{na}] 4$ & & F2 & $\mathrm{S}[\mathrm{an}]$ & $\mathrm{NVC}^{*}$ & $\mathrm{~S}[\mathrm{aa}] \mathrm{S}[\mathrm{na}] 4$ & & $\mathrm{G}$ & NVC & NVC \\
\hline $\mathrm{A}[\mathrm{aa}] \mathrm{S}[\mathrm{nn}] 4$ & & $\mathrm{H}$ & NVC & $\mathrm{NVC}$ & $\mathrm{S}[\mathrm{aa}] \mathrm{S}[\mathrm{nn}] 4$ & & $\mathrm{~F} 1$ & $\mathrm{NVC}^{*}$ & $\mathrm{~S}[\mathrm{an}]$ \\
\hline $\mathrm{A}[\mathrm{an}] \mathrm{A}[\mathrm{aa}] 4$ & EA4 & $\mathrm{F} 2$ & $\mathrm{~S}[\mathrm{an}]$ & $\mathrm{NVC}^{*}$ & $\mathrm{~S}[\mathrm{an}] \mathrm{A}[\mathrm{aa}] 4$ & OA4 & G & NVC & NVC \\
\hline $\mathrm{A}[\mathrm{an}] \mathrm{A}[\mathrm{an}] 4$ & EE4 & $\mathrm{G}$ & $\mathrm{NVC}^{*}$ & $\mathrm{NVC}^{*}$ & $\mathrm{~S}[\mathrm{an}] \mathrm{A}[\mathrm{an}] 4$ & OE4 & $\mathrm{G}$ & NVC & NVC \\
\hline $\mathrm{A}[\mathrm{an}] \mathrm{A}[\mathrm{na}] 4$ & & $\mathrm{C} 3$ & $\mathrm{~S}[\mathrm{aa}]$ & $\mathrm{A}[\mathrm{aa}]$ & $\mathrm{S}[\mathrm{an}] \mathrm{A}[\mathrm{na}] 4$ & & E1 & $\mathrm{S}[\mathrm{aa}]$ & $\mathrm{S}[\mathrm{aa}]$ \\
\hline $\mathrm{A}[\mathrm{an}] \mathrm{A}[\mathrm{nn}] 4$ & & $\mathrm{D}$ & $\mathrm{N}[\mathrm{aa}]^{*}$ & $\mathrm{~N}[\mathrm{aa}]^{*}$ & $\mathrm{~S}[\mathrm{an}] \mathrm{A}[\mathrm{nn}] 4$ & & F1 & $\mathrm{NVC}^{*}$ & $\mathrm{~S}[\mathrm{an}]$ \\
\hline $\mathrm{A}[\mathrm{an}] \mathrm{S}[\mathrm{aa}] 4$ & EI4 & $\mathrm{F} 2$ & $\mathrm{~S}[\mathrm{an}]$ & $\mathrm{NVC}^{*}$ & $\mathrm{~S}[\mathrm{an}] \mathrm{S}[\mathrm{aa}] 4$ & OI4 & $\mathrm{G}$ & NVC & NVC \\
\hline $\mathrm{A}[\mathrm{an}] \mathrm{S}[\mathrm{an}] 4$ & EO4 & $\mathrm{G}$ & $\mathrm{NVC}^{*}$ & $\mathrm{NVC}^{*}$ & $\mathrm{~S}[\mathrm{an}] \mathrm{S}[\mathrm{an}] 4$ & OO4 & $\mathrm{G}$ & NVC & NVC \\
\hline $\mathrm{A}[\mathrm{an}] \mathrm{S}[\mathrm{na}] 4$ & & G & NVC & NVC & $\mathrm{S}[\mathrm{an}] \mathrm{S}[\mathrm{na}] 4$ & & $\mathrm{G}$ & NVC & NVC \\
\hline $\mathrm{A}[\mathrm{an}] \mathrm{S}[\mathrm{nn}] 4$ & & F1 & $\mathrm{NVC}^{*}$ & $\mathrm{~S}[\mathrm{an}]$ & $\mathrm{S}[\mathrm{an}] \mathrm{S}[\mathrm{nn}] 4$ & & $\mathrm{~F} 1$ & $\mathrm{NVC}^{*}$ & $\mathrm{~S}[\mathrm{an}]$ \\
\hline $\mathrm{A}[\mathrm{na}] \mathrm{A}[\mathrm{aa}] 4$ & & $\mathrm{~F} 2$ & $\mathrm{~S}[\mathrm{an}]$ & $\mathrm{NVC}^{*}$ & $\mathrm{~S}[\mathrm{na}] \mathrm{A}[\mathrm{aa}] 4$ & & F2 & $\mathrm{S}[\mathrm{an}]$ & $\mathrm{NVC}^{*}$ \\
\hline A[na]A[an]4 & & $\mathrm{C} 1$ & $\mathrm{~A}[\mathrm{aa}]^{*}$ & $\mathrm{~S}[\mathrm{aa}]^{*}$ & $\mathrm{~S}[\mathrm{na}] \mathrm{A}[\mathrm{an}] 4$ & & $\mathrm{G}$ & $\mathrm{NVC}^{*}$ & $\mathrm{NVC}^{*}$ \\
\hline $\mathrm{A}[\mathrm{na}] \mathrm{A}[\mathrm{na}] 4$ & & E1 & $\mathrm{S}[\mathrm{aa}]$ & $\mathrm{S}[\mathrm{aa}]$ & $\mathrm{S}[\mathrm{na}] \mathrm{A}[\mathrm{na}] 4$ & & $\mathrm{G}$ & NVC & NVC \\
\hline $\mathrm{A}[\mathrm{na}] \mathrm{A}[\mathrm{nn}] 4$ & & F1 & $\mathrm{NVC}^{*}$ & $\mathrm{~S}[\mathrm{an}]$ & $\mathrm{S}[\mathrm{na}] \mathrm{A}[\mathrm{nn}] 4$ & & F1 & $\mathrm{NVC}^{*}$ & $\mathrm{~S}[\mathrm{an}]$ \\
\hline $\mathrm{A}[\mathrm{na}] \mathrm{S}[\mathrm{aa}] 4$ & & $\mathrm{G}$ & NVC & NVC & $\mathrm{S}[\mathrm{na}] \mathrm{S}[\mathrm{aa}] 4$ & & $\mathrm{G}$ & NVC & NVC \\
\hline $\mathrm{A}[\mathrm{na}] \mathrm{S}[\mathrm{an}] 4$ & & G & NVC & NVC & $\mathrm{S}[\mathrm{na}] \mathrm{S}[\mathrm{an}] 4$ & & $\mathrm{G}$ & NVC & NVC \\
\hline $\mathrm{A}[\mathrm{na}] \mathrm{S}[\mathrm{na}] 4$ & & E1 & $\mathrm{S}[\mathrm{aa}]$ & $\mathrm{S}[\mathrm{aa}]$ & $\mathrm{S}[\mathrm{na}] \mathrm{S}[\mathrm{na}] 4$ & & $\mathrm{G}$ & $\mathrm{NVC}$ & NVC \\
\hline $\mathrm{A}[\mathrm{na}] \mathrm{S}[\mathrm{nn}] 4$ & & $\mathrm{~F} 1$ & $\mathrm{NVC}^{*}$ & $\mathrm{~S}[\mathrm{an}]$ & $\mathrm{S}[\mathrm{na}] \mathrm{S}[\mathrm{nn}] 4$ & & $\mathrm{~F} 1$ & $\mathrm{NVC}^{*}$ & $\mathrm{~S}[\mathrm{an}]$ \\
\hline $\mathrm{A}[\mathrm{nn}] \mathrm{A}[\mathrm{aa}] 4$ & & E3 & $\mathrm{S}[\mathrm{aa}] \mathrm{S}[\mathrm{an}]$ & $\mathrm{S}[\mathrm{aa}]^{*}$ & $\mathrm{~S}[\mathrm{nn}] \mathrm{A}[\mathrm{aa}] 4$ & & $\mathrm{~F} 2$ & $\mathrm{~S}[\mathrm{an}]$ & $\mathrm{NVC}^{*}$ \\
\hline $\mathrm{A}[\mathrm{nn}] \mathrm{A}[\mathrm{an}] 4$ & & F3 & $\mathrm{S}[\mathrm{an}]^{*}$ & $\mathrm{~S}[\mathrm{an}]^{*}$ & $\mathrm{~S}[\mathrm{nn}] \mathrm{A}[\mathrm{an}] 4$ & & $\mathrm{~F} 2$ & $\mathrm{~S}[\mathrm{an}]$ & $\mathrm{NVC}^{*}$ \\
\hline $\mathrm{A}[\mathrm{nn}] \mathrm{A}[\mathrm{na}] 4$ & & $\mathrm{~F} 2$ & $\mathrm{~S}[\mathrm{an}]$ & NVC $^{*}$ & $\mathrm{~S}[\mathrm{nn}] \mathrm{A}[\mathrm{na}] 4$ & & $\mathrm{~F} 2$ & $\mathrm{~S}[\mathrm{an}]$ & $\mathrm{NVC}^{*}$ \\
\hline $\mathrm{A}[\mathrm{nn}] \mathrm{A}[\mathrm{nn}] 4$ & & $\mathrm{H}$ & NVC & NVC & $\mathrm{S}[\mathrm{nn}] \mathrm{A}[\mathrm{nn}] 4$ & & $\mathrm{H}$ & NVC & NVC \\
\hline $\mathrm{A}[\mathrm{nn}] \mathrm{S}[\mathrm{aa}] 4$ & & E3 & $\mathrm{S}[\mathrm{aa}] \mathrm{S}[\mathrm{an}]$ & $\mathrm{S}[\mathrm{aa}]^{*}$ & $\mathrm{~S}[\mathrm{nn}] \mathrm{S}[\mathrm{aa}] 4$ & & $\mathrm{~F} 2$ & $\mathrm{~S}[\mathrm{an}]$ & $\mathrm{NVC}^{*}$ \\
\hline $\mathrm{A}[\mathrm{nn}] \mathrm{S}[\mathrm{an}] 4$ & & F3 & $\mathrm{S}[\mathrm{an}]^{*}$ & $\mathrm{~S}[\mathrm{an}]^{*}$ & $\mathrm{~S}[\mathrm{nn}] \mathrm{S}[\mathrm{an}] 4$ & & F2 & S[an] & $\mathrm{NVC}^{*}$ \\
\hline $\mathrm{A}[\mathrm{nn}] \mathrm{S}[\mathrm{na}] 4$ & & $\mathrm{~F} 2$ & $\mathrm{~S}[\mathrm{an}]$ & NVC $^{*}$ & $\mathrm{~S}[\mathrm{nn}] \mathrm{S}[\mathrm{na}] 4$ & & $\mathrm{~F} 2$ & S[an] & $\mathrm{NVC}^{*}$ \\
\hline $\mathrm{A}[\mathrm{nn}] \mathrm{S}[\mathrm{nn}] 4$ & & F3 & $\mathrm{S}[\mathrm{an}]^{*}$ & $\mathrm{~S}[\mathrm{an}]^{*}$ & $\mathrm{~S}[\mathrm{nn}] \mathrm{S}[\mathrm{nn}] 4$ & & F3 & $\mathrm{S}[\mathrm{an}]^{*}$ & $\mathrm{~S}[\mathrm{an}]^{*}$ \\
\hline
\end{tabular}




\section{APPENDIX C
Premise Pairs in Which $A l l$ Is the Strongest Conventional Valid Conclusion}

Items in this and the subsequent Appendices are grouped by outcome category (see Appendix A) so that premise pairs yielding identical valid conclusions can be readily identified. Premise pairs that are identical to the traditional 64 are given in boldface type, along with their traditional designation. Premise pairs on the same line are logically identical.

Not all valid conclusions are shown. Table 2 should be consulted to see whether equivalent conclusions with different permutations of negations are available. For example, if A[aa]CA is valid, so is N[an]CA. In addition, only the strongest valid conclusion is shown. For example, if A[aa]CA is a valid conclusion, so is S[aa]CA (see Table 2). Where valid conclusions with a negated first term are available, these are also shown, but again, only the strongest conclusion.

$\mathrm{C} 1$. Twenty premise pairs yield the following outcome sets and valid conclusions (only eight of these yield the additional asterisked conclusions):

\begin{tabular}{|c|}
\hline $\mathrm{A}=\mathrm{C}$ \\
\hline \\
\end{tabular}

$\begin{array}{lllll}\text { AA1 } & \text { A[aa]A[aa]1 } & \text { A[aa]N[an]1 } & \text { N[an]A[aa]1 } & \text { N[an]N[an]1 } \\ & \text { A[na]A[an]1 } & \text { A[na]N[aa]1 } & \text { N[nn]A[an]1 } & \text { N[nn]N[aa]1 } \\ \text { A[na]A[an]2* } & \text { A[na]N[aa]2* } & \text { N[nn]A[an]2* } & \text { N[nn]N[aa]2* } \\ \text { A[na]A[an]3 } & \text { A[na]N[aa]3 } & \text { N[nn]A[an]3 } & \text { N[nn]N[aa]3 } \\ \text { A[na]A[an]4* } & \text { A[na]N[aa]4* } & \text { N[nn]A[an]4* } & \text { N[nn]N[aa]4* }\end{array}$

C2. Four premise pairs yield the following outcome set and valid conclusions:

\begin{tabular}{|c|}
\hline A C C \\
\hline All C are A, Some A are C, Some A are not-C \\
All not-C are A \\
\hline
\end{tabular}

$\mathrm{A}[\mathrm{aa}] \mathrm{A}[\mathrm{nn}] 3 \quad \mathrm{~A}[\mathrm{aa}] \mathrm{N}[\mathrm{na}] 3 \quad \mathrm{~N}[\mathrm{an}] \mathrm{A}[\mathrm{nn}] 3 \quad \mathrm{~N}[\mathrm{an}] \mathrm{N}[\mathrm{na}] 3$

C3. Twenty premise pairs yield the following outcome sets and valid conclusions (only eight of these yield the additional asterisked conclusions):

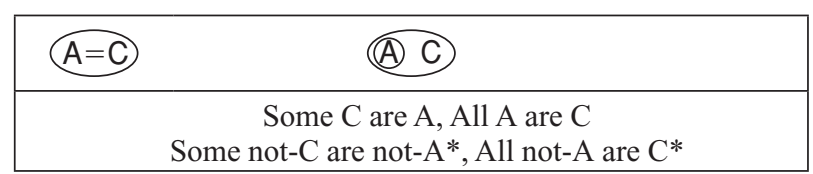

$\begin{array}{cllll} & \text { A[an]A[na]1* } & \text { A[an]N[nn]1* } & \text { N[aa]A[na]1* } & \text { N[aa]N[nn]1* } \\ & \text { A[an]A[na]2* } & \text { A[an]N[nn]2* } & \text { N[aa]A[na]2* } & \text { N[aa]N[nn]2* } \\ \text { AA4 } & \text { A[an]A[na]3 } & \text { A[an]N[nn]3 } & \text { N[aa]A[na]3 } & \text { N[aa]N[nn]3 } \\ & \text { A[aa]A[aa]4 } & \text { A[aa]N[an]4 } & \text { N[an]A[aa]4 } & \text { N[an]N[an]4 } \\ & \text { A[an]A[na]4 } & \text { A[an]N[nn]4 } & \text { N[aa]A[na]4 } & \text { N[aa]N[nn]4 }\end{array}$

C4. Four premise pairs yield the following outcome set and valid conclusions:

\begin{tabular}{|c|}
\hline A $\mathrm{C}$ \\
\hline Some $\mathrm{C}$ are A, Some C are not-A, All A are C \\
All not-A are C \\
\hline
\end{tabular}

$\mathrm{A}[\mathrm{nn}] \mathrm{A}[\mathrm{aa}] 3 \quad \mathrm{~A}[\mathrm{nn}] \mathrm{N}[\mathrm{an}] 3 \quad \mathrm{~N}[\mathrm{na}] \mathrm{A}[\mathrm{aa}] 3 \quad \mathrm{~N}[\mathrm{na}] \mathrm{N}[\mathrm{an}] 3$


APPENDIX D

Premise Pairs in Which None Is the Strongest Conventional Valid Conclusion

D. Thirty-two premise pairs yield the following outcome set and valid conclusions:

\begin{tabular}{|c|}
\hline (A) C \\
\hline No C are A, No A are C \\
Some not-C are A, Some not-A are C
\end{tabular}

$\begin{array}{lllll}\text { EA1 } & \text { A[an]A[aa]1 } & \text { A[an]N[an]1 } & \text { N[aa]A[aa]1 } & \text { N[aa]N[an]1 } \\ & \text { A[nn]A[an]1 } & \text { A[nn]N[aa]1 } & \text { N[na]A[an]1 } & \text { N[na]N[aa]1 } \\ \text { AE2 } & \text { A[aa]A[an]2 } & \text { A[aa]N[aa]2 } & \text { N[an]A[an]2 } & \text { N[an]N[aa]2 } \\ \text { EA2 } & \text { A[an]A[aa]2 } & \text { A[an]N[an]2 } & \text { N[aa]A[aa]2 } & \text { N[aa]N[an]2 } \\ & \text { A[an]A[nn]3 } & \text { A[an]N[na]3 } & \text { N[aa]A[nn]3 } & \text { N[aa]N[na]3 } \\ & \text { A[nn]A[an]3 } & \text { A[nn]N[aa]3 } & \text { N[na]A[an]3 } & \text { N[na]N[aa]3 } \\ \text { AE4 } & \text { A[aa]A[an]4 } & \text { A[aa]N[aa]4 } & \text { N[an]A[an]4 } & \text { N[an]N[aa]4 } \\ & \text { A[an]A[nn]4 } & \text { A[an]N[na]4 } & \text { N[aa]A[nn]4 } & \text { N[aa]N[na]4 }\end{array}$


APPENDIX E

Premise Pairs in Which Some Is the Strongest Conventional Valid Conclusion

E1. Forty premise pairs yield the following outcome sets and valid conclusions:

\begin{tabular}{|c|c|}
\hline$A=C$ & A C A C AC A \\
\hline \multicolumn{4}{|c|}{ Some $\mathrm{C}$ are $\mathrm{A}$, Some $\mathrm{A}$ are $\mathrm{C}$} \\
\hline
\end{tabular}

AI1

\begin{tabular}{|c|c|c|c|}
\hline A[aa]S[aa]1 & $\mathrm{N}[\mathrm{an}] \mathrm{S}[\mathrm{aa}] 1$ & & \\
\hline $\mathrm{A}[\mathrm{na}] \mathrm{A}[\mathrm{na}] 1$ & $\mathrm{~A}[\mathrm{na}] \mathrm{N}[\mathrm{nn}] 1$ & $\mathrm{~N}[\mathrm{nn}] \mathrm{A}[\mathrm{na}] 1$ & $\mathrm{~N}[\mathrm{nn}] \mathrm{N}[\mathrm{nn}] 1$ \\
\hline $\mathrm{A}[\mathrm{na}] \mathrm{S}[\mathrm{an}] 1$ & N[nn]S[an]1 & & \\
\hline $\mathrm{S}[\mathrm{na}] \mathrm{A}[\mathrm{na}] 1$ & $\mathrm{~S}[\mathrm{na}] \mathrm{N}[\mathrm{nn}] 1$ & & \\
\hline $\mathrm{A}[$ na]S[an]2 & $\mathrm{N}[\mathrm{nn}] \mathrm{S}[\mathrm{an}] 2$ & & \\
\hline $\mathrm{S}[\mathrm{an}] \mathrm{A}[\mathrm{na}] 2$ & $\mathrm{~S}[\mathrm{an}] \mathrm{N}[\mathrm{nn}] 2$ & & \\
\hline A[aa]A[aa]3 & $\mathrm{A}[\mathrm{aa}] \mathrm{N}[\mathrm{an}] 3$ & $\mathrm{~N}[\mathrm{an}] \mathrm{A}[\mathrm{aa}] 3$ & $\mathrm{~N}[\mathrm{an}] \mathrm{N}[\mathrm{an}] 3$ \\
\hline $\mathbf{A}[\mathbf{a a}] \mathrm{S}[\mathbf{a a}] \mathbf{3}$ & $\mathrm{N}[\mathrm{an}] \mathrm{S}[\mathrm{aa}] 3$ & & \\
\hline $\mathrm{A}[\mathrm{na}] \mathrm{A}[\mathrm{na}] 3$ & $\mathrm{~A}[\mathrm{na}] \mathrm{N}[\mathrm{nn}] 3$ & $\mathrm{~N}[\mathrm{nn}] \mathrm{A}[\mathrm{na}] 3$ & $\mathrm{~N}[\mathrm{nn}] \mathrm{N}[\mathrm{nn}] 3$ \\
\hline $\mathrm{A}[\mathrm{na}] \mathrm{S}[\mathrm{na}] 3$ & $N[n n] S[n a] 3$ & & \\
\hline S[aa]A[aa]3 & $\mathrm{S}[\mathrm{aa}] \mathrm{N}[\mathrm{an}] 3$ & & \\
\hline $\mathrm{S}[\mathrm{na}] \mathrm{A}[\mathrm{na}] 3$ & $\mathrm{~S}[\mathrm{na}] \mathrm{N}[\mathrm{nn}] 3$ & & \\
\hline $\mathrm{A}[\mathrm{na}] \mathrm{A}[\mathrm{na}] 4$ & $\mathrm{~A}[\mathrm{na}] \mathrm{N}[\mathrm{nn}] 4$ & $\mathrm{~N}[\mathrm{nn}] \mathrm{A}[\mathrm{na}] 4$ & $\mathrm{~N}[\mathrm{nn}] \mathrm{N}[\mathrm{nn}] 4$ \\
\hline $\mathrm{A}[\mathrm{na}] \mathrm{S}[\mathrm{na}] 4$ & $\mathrm{~N}[\mathrm{nn}] \mathrm{S}[\mathrm{na}] 4$ & & \\
\hline S[aa]A[aa]4 & $\mathrm{S}[\mathrm{aa}] \mathrm{N}[\mathrm{an}] 4$ & & \\
\hline $\mathrm{S}[\mathrm{an}] \mathrm{A}[\mathrm{na}] 4$ & $\mathrm{~S}[\mathrm{an}] \mathrm{N}[\mathrm{nn}] 4$ & & \\
\hline
\end{tabular}

E2. Eight premise pairs yield the following outcome sets and valid conclusions:

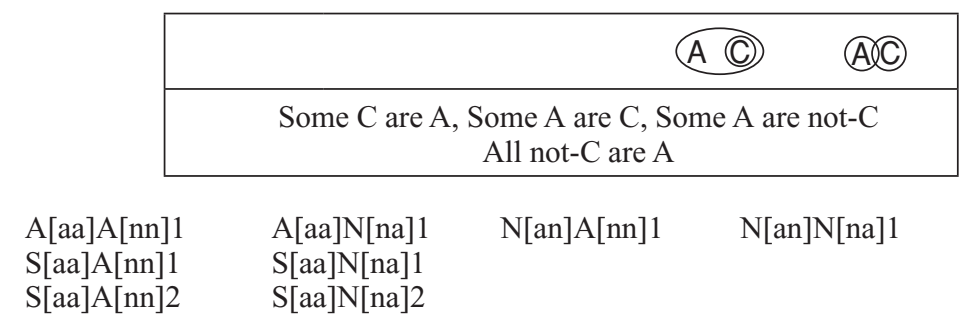

E3. Eight premise pairs yield the following outcome sets and valid conclusions:

(A) C AC

Some $\mathrm{C}$ are A, Some C are not-A, Some A are C All not-A are $\mathrm{C}$

$\begin{array}{llll}\mathrm{A}[\mathrm{nn}] \mathrm{S}[\mathrm{aa}] 2 & \mathrm{~N}[\mathrm{na}] \mathrm{S}[\mathrm{aa}] 2 & & \\ \mathrm{~A}[\mathrm{nn}] \mathrm{A}[\mathrm{aa}] 4 & \mathrm{~A}[\mathrm{nn}] \mathrm{N}[\mathrm{an}] 4 & \mathrm{~N}[\mathrm{na}] \mathrm{A}[\mathrm{aa}] 4 & \mathrm{~N}[\mathrm{na}] \mathrm{N}[\mathrm{an}] 4 \\ \mathrm{~A}[\mathrm{nn}] \mathrm{S}[\mathrm{aa}] 4 & \mathrm{~N}[\mathrm{na}] \mathrm{S}[\mathrm{aa}] 4 & & \end{array}$

E4. Four premise pairs yield the following outcome set and valid conclusions:

\begin{tabular}{|c|}
\hline \\
\hline Some C are A, Some A are C \\
Some C are not-A, Some A are not-C \\
All not-C are A, All not-A are C \\
\hline
\end{tabular}

$\mathrm{A}[\mathrm{nn}] \mathrm{A}[\mathrm{nn}] 2 \quad \mathrm{~A}[\mathrm{nn}] \mathrm{N}[\mathrm{na}] 2 \quad \mathrm{~N}[\mathrm{na}] \mathrm{A}[\mathrm{nn}] 2 \quad \mathrm{~N}[\mathrm{na}] \mathrm{N}[\mathrm{na}] 2$


APPENDIX F

Premise Pairs in Which Some ... Not Is the Strongest Conventional Valid Conclusion

F1. Ninety-two premise pairs yield the following outcome sets and valid conclusions ( 28 of these additionally yield the asterisked conclusion):

\begin{tabular}{|c|c|}
\hline (A) (C) & A C C \\
\hline \multicolumn{3}{|c|}{ Some A are not-C } \\
All not-C are A*, Some not-C are A \\
\hline
\end{tabular}

AE1

\section{$\mathrm{A}[\mathrm{aa}] \mathrm{A}[\mathrm{an}] 1^{*}$}

$\mathrm{A}[\mathrm{aa}] \mathrm{A}[\mathrm{na}] 1^{*}$

$\mathrm{A}[\mathrm{aa}] \mathrm{S}[\mathrm{na}] 1^{*}$

$\mathrm{A}[\mathrm{aa}] \mathrm{S}[\mathrm{nn}] 1^{*}$

$\mathrm{A}[\mathrm{an}] \mathrm{S}[\mathrm{nn}] 1$

$\mathrm{A}[$ na]A[aa]1

$\mathrm{A}[\mathrm{na}] \mathrm{A}[\mathrm{nn}] 1^{*}$

$\mathrm{A}[\mathrm{na}] \mathrm{S}[\mathrm{nn}] 1$

IE1 S[aa]A[an]1

S[aa]S[nn]1

$\mathrm{S}[\mathrm{an}] \mathrm{S}[\mathrm{nn}] 1$

$\mathrm{S}[\mathrm{na}] \mathrm{A}[\mathrm{aa}] 1$

$\mathrm{S}[\mathrm{na}] \mathrm{A}[\mathrm{nn}] 1^{*}$

$\mathrm{S}[\mathrm{na}] \mathrm{S}[\mathrm{nn}] 1$

$\mathrm{A}[\mathrm{an}] \mathrm{S}[\mathrm{nn}] 2$

$\mathrm{A}[\mathrm{na}] \mathrm{S}[\mathrm{nn}] 2$

IE2 S[aa]A[an]2

$\mathrm{S}[\mathrm{aa}] \mathrm{S}[\mathrm{nn}] 2$

OE2 S[an]A[aa]2

$\mathrm{S}[\mathrm{an}] \mathrm{A}[\mathrm{nn}] 2 *$

$\mathrm{S}[\mathrm{an}] \mathrm{S}[\mathrm{nn}] 2$

$\mathrm{S}[\mathrm{na}] \mathrm{S}[\mathrm{nn}] 2$

AE3 A[aa]A[an]3*

AO3 A[aa]S[an]3*

$\mathrm{A}[\mathrm{aa}] \mathrm{S}[\mathrm{nn}] 3^{*}$

$\mathrm{A}[\mathrm{an}] \mathrm{S}[\mathrm{nn}] 3$

$\mathrm{A}[\mathrm{na}] \mathrm{A}[\mathrm{nn}] 3$

$\mathrm{A}[\mathrm{na}] \mathrm{S}[\mathrm{nn}] 3$

IE3 S[aa]A[an]3

$\mathrm{S}[\mathrm{aa}] \mathrm{A}[\mathrm{nn}] 3$

$\mathrm{S}[\mathrm{aa}] \mathrm{S}[\mathrm{nn}] 3$

$\mathrm{S}[\mathrm{an}] \mathrm{A}[\mathrm{nn}] 3$

$\mathrm{S}[\mathrm{an}] \mathrm{S}[\mathrm{nn}] 3$

$\mathrm{S}[\mathrm{na}] \mathrm{A}[\mathrm{nn}] 3$

$\mathrm{S}[\mathrm{na}] \mathrm{S}[\mathrm{nn}] 3$

A[an]S[nn]4

$\mathrm{A}[\mathrm{na}] \mathrm{A}[\mathrm{nn}] 4$

$\mathrm{A}[\mathrm{na}] \mathrm{S}[\mathrm{nn}] 4$

IE4 S[aa]A[an]4

$\mathrm{S}[\mathrm{aa}] \mathrm{A}[\mathrm{nn}] 4$

$\mathrm{S}[\mathrm{aa}] \mathrm{S}[\mathrm{nn}] 4$

$\mathrm{S}[\mathrm{an}] \mathrm{A}[\mathrm{nn}] 4$

$\mathrm{S}[\mathrm{an}] \mathrm{S}[\mathrm{nn}] 4$

$\mathrm{S}[\mathrm{na}] \mathrm{A}[\mathrm{nn}] 4$

$\mathrm{S}[\mathrm{na}] \mathrm{S}[\mathrm{nn}] 4$
A[aa]N[aa]1*

$\mathrm{A}[\mathrm{aa}] \mathrm{N}[\mathrm{nn}] 1^{*}$

$\mathrm{N}$ [an]S[na] $1^{*}$

$\mathrm{N}[\mathrm{an}] \mathrm{S}[\mathrm{nn}] 1 *$

$\mathrm{N}[\mathrm{aa}] \mathrm{S}[\mathrm{nn}] 1$

$\mathrm{A}[\mathrm{na}] \mathrm{N}[\mathrm{an}] 1$

$\mathrm{A}[$ na]N[na] 1 *

$\mathrm{N}[\mathrm{nn}] \mathrm{S}[\mathrm{nn}] 1$

S[aa]N[aa]1

$\mathrm{S}[\mathrm{na}] \mathrm{N}[\mathrm{an}] 1$

$\mathrm{S}[\mathrm{na}] \mathrm{N}[\mathrm{na}] 1$ *

$\mathrm{N}[\mathrm{aa}] \mathrm{S}[\mathrm{nn}] 2$

$\mathrm{N}[\mathrm{nn}] \mathrm{S}[\mathrm{nn}] 2$

S[aa]N[aa]2

$\mathrm{S}[\mathrm{an}] \mathrm{N}[\mathrm{an}] 2$

$\mathrm{S}[\mathrm{an}] \mathrm{N}[\mathrm{na}] 2 *$

A[aa]N[aa]3*

$\mathrm{N}[\mathrm{an}] \mathrm{S}[\mathrm{an}] 3^{*}$

$\mathrm{N}[\mathrm{an}] \mathrm{S}[\mathrm{nn}] 3^{*}$

$\mathrm{N}[\mathrm{aa}] \mathrm{S}[\mathrm{nn}] 3$

$\mathrm{A}[$ na]N[na]3

$\mathrm{N}[\mathrm{nn}] \mathrm{S}[\mathrm{nn}] 3$

S[aa]N[aa]3

$\mathrm{S}[\mathrm{aa}] \mathrm{N}[\mathrm{na}] 3$

$\mathrm{S}[\mathrm{an}] \mathrm{N}[\mathrm{na}] 3$

$\mathrm{S}[$ na $] \mathrm{N}[\mathrm{na}] 3$

$\mathrm{N}[\mathrm{aa}] \mathrm{S}[\mathrm{nn}] 4$

A[na]N[na]4

$\mathrm{N}[\mathrm{nn}] \mathrm{S}[\mathrm{nn}] 4$

S[aa]N[aa]4

$\mathrm{S}[\mathrm{aa}] \mathrm{N}[\mathrm{na}] 4$

$\mathrm{S}[\mathrm{an}] \mathrm{N}[\mathrm{na}] 4$

$\mathrm{S}[\mathrm{na}] \mathrm{N}[\mathrm{na}] 4$
$\mathrm{N}[\mathrm{an}] \mathrm{A}[\mathrm{an}] 1 * \quad \mathrm{~N}[\mathrm{an}] \mathrm{N}[\mathrm{aa}] 1 *$

$\mathrm{N}[\mathrm{an}] \mathrm{A}[\mathrm{na}] 1 * \quad \mathrm{~N}[\mathrm{an}] \mathrm{N}[\mathrm{nn}] 1 *$

$\mathrm{N}[\mathrm{nn}] \mathrm{A}[\mathrm{aa}] 1 \quad \mathrm{~N}[\mathrm{nn}] \mathrm{N}[\mathrm{an}] 1$

$\mathrm{N}[\mathrm{nn}] \mathrm{A}[\mathrm{nn}] 1 * \quad \mathrm{~N}[\mathrm{nn}] \mathrm{N}[\mathrm{na}] 1^{*}$

$\mathrm{N}[\mathrm{an}] \mathrm{A}[\mathrm{an}] 3 * \quad \mathrm{~N}[\mathrm{an}] \mathrm{N}[\mathrm{aa}] 3 *$

$\mathrm{N}[\mathrm{nn}] \mathrm{A}[\mathrm{nn}] 3 \quad \mathrm{~N}[\mathrm{nn}] \mathrm{N}[\mathrm{na}] 3$

$\mathrm{N}[\mathrm{nn}] \mathrm{A}[\mathrm{nn}] 4 \quad \mathrm{~N}[\mathrm{nn}] \mathrm{N}[\mathrm{na}] 4$ 
APPENDIX F (Continued)

F2. Ninety-two premise pairs yield the following outcome sets and valid conclusions (28 of these additionally yield the asterisked conclusion):

\begin{tabular}{|cc|}
\hline (A) C AC C A C & (A) \\
\hline \multicolumn{3}{|c|}{ Some C are not-A } \\
All not-A are C*, Some not-A are C \\
\hline
\end{tabular}

EI1

$\mathrm{A}[\mathrm{an}] \mathrm{S}[\mathrm{aa}] 1 \quad \mathrm{~N}$ [aa]S[aa]1

$\mathrm{A}[\mathrm{nn}] \mathrm{A}[\mathrm{na}] 1 \quad \mathrm{~A}[\mathrm{nn}] \mathrm{N}[\mathrm{nn}] 1$

$\mathrm{A}[\mathrm{nn}] \mathrm{S}[\mathrm{aa}] 1 \quad \mathrm{~N}[\mathrm{na}] \mathrm{S}[\mathrm{aa}] 1$

$\mathrm{A}[\mathrm{nn}] \mathrm{S}[\mathrm{an}] 1 \quad \mathrm{~N}[\mathrm{na}] \mathrm{S}[\mathrm{an}] 1$

$\mathrm{A}[\mathrm{nn}] \mathrm{S}[\mathrm{na}] 1 \quad \mathrm{~N}$ [na]S[na]1

$\mathrm{S}[\mathrm{nn}] \mathrm{A}[\mathrm{an}] 1 \quad \mathrm{~S}[\mathrm{nn}] \mathrm{N}[\mathrm{aa}] 1$

$\mathrm{S}[\mathrm{nn}] \mathrm{A}[\mathrm{na}] 1 \quad \mathrm{~S}[\mathrm{nn}] \mathrm{N}[\mathrm{nn}] 1$

$\mathrm{S}[\mathrm{nn}] \mathrm{S}[\mathrm{aa}] 1$

$\mathrm{S}[\mathrm{nn}] \mathrm{S}[\mathrm{an}] 1$

S[nn]S[na]

$\mathrm{AO2}$ A[aa]S[an]2

EI2 A[an]S[aa]2

$\mathrm{A}[\mathrm{nn}] \mathrm{S}[\mathrm{an}] 2 *$

$\mathrm{N}[\mathrm{an}] \mathrm{S}[\mathrm{an}] 2$

N[aa]S[aa] 2

$\mathrm{S}[\mathrm{nn}] \mathrm{A}[\mathrm{an}] 2$

$\mathrm{N}[$ na]S[an]2*

$\mathrm{S}[\mathrm{nn}] \mathrm{A}[\mathrm{na}] 2$

$\mathrm{S}[\mathrm{nn}] \mathrm{S}[\mathrm{aa}] 2$

$\mathrm{S}[\mathrm{nn}] \mathrm{S}[\mathrm{an}] 2$

$\mathrm{S}[\mathrm{nn}] \mathrm{S}[\mathrm{na}] 2$

EA3 A[an]A[aa]3*

$\mathrm{S}[\mathrm{nn}] \mathrm{N}[\mathrm{aa}] 2$

$\mathrm{S}[\mathrm{nn}] \mathrm{N}[\mathrm{nn}] 2$

EI3 A[an]S[aa]3

$\mathrm{A}[\mathrm{nn}] \mathrm{A}[\mathrm{na}] 3$

$\mathrm{A}[\mathrm{nn}] \mathrm{S}[\mathrm{aa}] 3$

$\mathrm{A}[\mathrm{nn}] \mathrm{S}[\mathrm{an}] 3$

$\mathrm{A}[\mathrm{nn}] \mathrm{S}[\mathrm{na}] 3$

$\mathrm{A}[\mathrm{an}] \mathrm{N}[\mathrm{an}] 3^{*}$

N[aa]S[aa]3

$\mathrm{A}[\mathrm{nn}] \mathrm{N}[\mathrm{nn}] 3$

$\mathrm{N}[\mathrm{na}] \mathrm{S}[\mathrm{aa}] 3$

$\mathrm{N}[$ na]S[an]3

OA3 S[an]A[aa]3* S[an]N[an] 3*

$\mathrm{S}[\mathrm{nn}] \mathrm{A}[\mathrm{aa}] 3^{*}$

$\mathrm{S}[\mathrm{nn}] \mathrm{A}[\mathrm{an}] 3$

$\mathrm{S}[\mathrm{nn}] \mathrm{N}[\mathrm{an}] 3 *$

$\mathrm{S}[\mathrm{nn}] \mathrm{N}[\mathrm{aa}] 3$

$\mathrm{S}[\mathrm{nn}] \mathrm{A}[\mathrm{na}] 3$

$\mathrm{S}[\mathrm{nn}] \mathrm{N}[\mathrm{nn}] 3$

$\mathrm{S}[\mathrm{nn}] \mathrm{S}[\mathrm{aa}] 3$

$\mathrm{S}[\mathrm{nn}] \mathrm{S}[\mathrm{an}] 3$

$\mathrm{S}[\mathrm{nn}] \mathrm{S}[\mathrm{na}] 3$

$\mathrm{A}[\mathrm{aa}] \mathrm{A}[\mathrm{na}] 4$

$\mathrm{A}[\mathrm{aa}] \mathrm{S}[\mathrm{na}] 4$

EA4 A[an]A[aa]4*

EI4 A[an]S[aa]4

$\mathrm{A}[\mathrm{na}] \mathrm{A}[\mathrm{aa}] 4 *$

$\mathrm{A}[\mathrm{nn}] \mathrm{A}[\mathrm{na}] 4 *$

$\mathrm{A}[\mathrm{nn}] \mathrm{S}[\mathrm{na}] 4 *$

$\mathrm{S}[\mathrm{na}] \mathrm{A}[\mathrm{aa}] 4 *$

$\mathrm{S}[\mathrm{nn}] \mathrm{A}[\mathrm{aa}] 4^{*}$

$\mathrm{A}[\mathrm{aa}] \mathrm{N}[\mathrm{nn}] 4$

$\mathrm{N}[\mathrm{an}] \mathrm{S}[\mathrm{na}] 4$

$\mathrm{N}[\mathrm{na}] \mathrm{A}[\mathrm{na}] 1 \quad \mathrm{~N}[\mathrm{na}] \mathrm{N}[\mathrm{nn}] 1$

$\mathrm{S}[\mathrm{nn}] \mathrm{A}[\mathrm{an}] 4$

$\mathrm{A}[\mathrm{an}] \mathrm{N}[\mathrm{an}] 4 *$

N[aa]S[aa]4

$\mathrm{A}[\mathrm{na}] \mathrm{N}[\mathrm{an}] 4$ *

$\mathrm{A}[\mathrm{nn}] \mathrm{N}[\mathrm{nn}] 4 *$

$\mathrm{N}[$ na $] \mathrm{S}[\mathrm{na}] 4^{*}$

N[aa]A[aa]3* $\mathrm{N}[\mathrm{aa}] \mathrm{N}[\mathrm{an}] 3^{*}$

$\mathrm{N}[$ na $] \mathrm{A}[\mathrm{na}] 3 \quad \mathrm{~N}[\mathrm{na}] \mathrm{N}[\mathrm{nn}] 3$

$\mathrm{S}[\mathrm{na}] \mathrm{N}[\mathrm{an}] 4^{*}$

S[nn]N[an]4*

$\mathrm{S}[\mathrm{nn}] \mathrm{N}[\mathrm{aa}] 4$

S[nn]A[na]4

$\mathrm{S}[\mathrm{nn}] \mathrm{N}[\mathrm{nn}] 4$

$\begin{array}{ll}\mathrm{N}[\mathrm{an}] \mathrm{A}[\mathrm{na}] 4 & \mathrm{~N}[\mathrm{an}] \mathrm{N}[\mathrm{nn}] 4 \\ \text { N[aa]A[aa]4* } & \mathrm{N}[\mathrm{aa}] \mathrm{N}[\mathrm{an}] 4 * \\ & \\ \mathrm{~N}[\mathrm{nn}] \mathrm{A}[\mathrm{aa}] 4 * & \mathrm{~N}[\mathrm{nn}] \mathrm{N}[\mathrm{an}] 4 * \\ \mathrm{~N}[\mathrm{na}] \mathrm{A}[\mathrm{na}] 4 * & \mathrm{~N}[\mathrm{na}] \mathrm{N}[\mathrm{nn}] 4 *\end{array}$

$\mathrm{S}[\mathrm{nn}] \mathrm{S}[\mathrm{aa}]$

$\mathrm{S}$ [nn]S[an]4

$\mathrm{S}[\mathrm{nn}] \mathrm{S}[\mathrm{na}] 4$ 
APPENDIX F (Continued)

F3. Forty-four premise pairs yield the following outcome sets and valid conclusions (40 of these additionally yield the asterisked conclusions):

\begin{tabular}{|c|c|c|c|}
\hline & (A) (C) & & (A) \\
\hline & $\begin{array}{l}\text { Some } \mathrm{C} \text {. } \\
\text { Some not } \\
\text { All not- }\end{array}$ & $\begin{array}{l}\text { not-A, Some A } \\
\text { are A, Some no } \\
\text { are A*, All not- }\end{array}$ & $\begin{array}{l}\text { not-C } \\
\text { are C } \\
\text { re } C^{*}\end{array}$ \\
\hline $\mathrm{A}[\mathrm{an}] \mathrm{A}[\mathrm{nn}] 1^{*}$ & $\mathrm{~A}[\mathrm{an}] \mathrm{N}[\mathrm{na}] 1 *$ & $\mathrm{~N}[\mathrm{aa}] \mathrm{A}[\mathrm{nn}] 1^{*}$ & $\mathrm{~N}[\mathrm{aa}] \mathrm{N}[\mathrm{na}] 1^{*}$ \\
\hline $\mathrm{S}[\mathrm{an}] \mathrm{A}[\mathrm{nn}] 1 *$ & $\mathrm{~S}[\operatorname{an}] \mathrm{N}[\mathrm{na}] 1^{*}$ & & \\
\hline $\begin{array}{l}\text { S[nn]A[nn]1* } \\
\text { S[nn]S[nn]1 }\end{array}$ & $\mathrm{S}[\mathrm{nn}] \mathrm{N}[\mathrm{na}] 1 *$ & & \\
\hline $\mathrm{A}[\mathrm{an}] \mathrm{A}[\mathrm{nn}] 2 *$ & $\mathrm{~A}[\mathrm{an}] \mathrm{N}[\mathrm{na}] 2 *$ & $\mathrm{~N}[\mathrm{aa}] \mathrm{A}[\mathrm{nn}] 2^{*}$ & $\mathrm{~N}[\mathrm{aa}] \mathrm{N}[\mathrm{na}] 2 *$ \\
\hline $\mathrm{A}[\mathrm{na}] \mathrm{A}[\mathrm{nn}] 2 *$ & $\mathrm{~A}[\mathrm{na}] \mathrm{N}[\mathrm{na}] 2 *$ & $\mathrm{~N}[\mathrm{nn}] \mathrm{A}[\mathrm{nn}] 2 *$ & $\mathrm{~N}[\mathrm{nn}] \mathrm{N}[\mathrm{na}] 2 *$ \\
\hline $\mathrm{A}[\mathrm{nn}] \mathrm{A}[\mathrm{an}] 2 *$ & $\mathrm{~A}[\mathrm{nn}] \mathrm{N}[\mathrm{aa}] 2 *$ & $\mathrm{~N}[\mathrm{na}] \mathrm{A}[\mathrm{an}] 2 *$ & $\mathrm{~N}[$ na $] \mathrm{N}[\mathrm{aa}] 2 *$ \\
\hline $\mathrm{A}[\mathrm{nn}] \mathrm{A}[\mathrm{na}] 2 *$ & $\mathrm{~A}[\mathrm{nn}] \mathrm{N}[\mathrm{nn}] 2^{*}$ & $\mathrm{~N}[$ na $] \mathrm{A}[\mathrm{na}] 2 *$ & $\mathrm{~N}[\mathrm{na}] \mathrm{N}[\mathrm{nn}] 2 *$ \\
\hline $\mathrm{A}[\mathrm{nn}] \mathrm{S}[\mathrm{na}] 2 *$ & $\mathrm{~N}[\mathrm{na}] \mathrm{S}[\mathrm{na}] 2 *$ & & \\
\hline $\mathrm{A}[\mathrm{nn}] \mathrm{S}[\mathrm{nn}] 2 *$ & $\mathrm{~N}[\mathrm{na}] \mathrm{S}[\mathrm{nn}] 2 *$ & & \\
\hline $\mathrm{S}[\mathrm{na}] \mathrm{A}[\mathrm{nn}] 2 *$ & $\mathrm{~S}[$ na]N[na]2* & & \\
\hline $\mathrm{S}[\mathrm{nn}] \mathrm{A}[\mathrm{nn}] 2 *$ & $\mathrm{~S}[\mathrm{nn}] \mathrm{N}[\mathrm{na}] 2 *$ & & \\
\hline $\mathrm{S}[\mathrm{nn}] \mathrm{S}[\mathrm{nn}] 2$ & & & \\
\hline $\mathrm{S}[\mathrm{nn}] \mathrm{S}[\mathrm{nn}] 3$ & & & \\
\hline $\mathrm{A}[\mathrm{nn}] \mathrm{A}[\mathrm{an}] 4 *$ & $\mathrm{~A}[\mathrm{nn}] \mathrm{N}[\mathrm{aa}] 4 *$ & $\mathrm{~N}[\mathrm{na}] \mathrm{A}[\mathrm{an}] 4$ & $\mathrm{~N}[\mathrm{na}] \mathrm{N}[\mathrm{aa}] 4 * *$ \\
\hline $\mathrm{A}[\mathrm{nn}] \mathrm{S}[\mathrm{an}] 4 *$ & $\mathrm{~N}[\mathrm{na}] \mathrm{S}[\mathrm{an}] 4^{*}$ & & \\
\hline $\mathrm{A}[\mathrm{nn}] \mathrm{S}[\mathrm{nn}] 4^{*}$ & $\mathrm{~N}[\mathrm{na}] \mathrm{S}[\mathrm{nn}] 4^{*}$ & & \\
\hline $\mathrm{S}[\mathrm{nn}] \mathrm{S}[\mathrm{nn}] 4$ & & & \\
\hline
\end{tabular}




\section{APPENDIX G \\ Premise Pairs in Which There Is No Conventional Valid Conclusion}

One hundred sixty-four premise pairs yield the following outcome sets and no valid conclusion at all. However, the 32 asterisked premise pairs yield two nonstandard valid conclusions:

[N.B.: Where no figure number is given, all four figures yield the same outcome sets; also, on rows 1 and 2, premise pairs on the same row are not logically equivalent.]

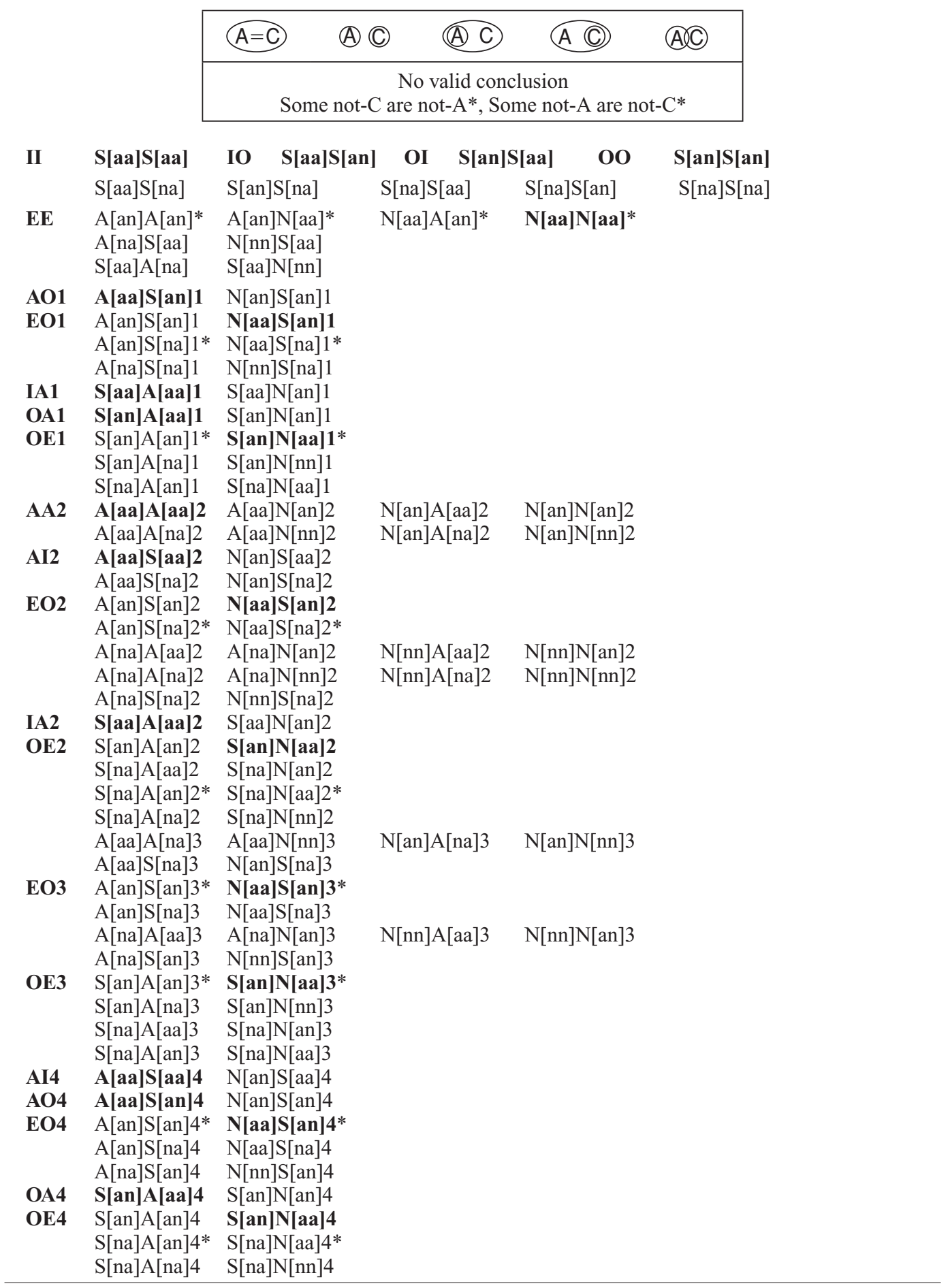


APPENDIX H

Premise Pairs in Which There Is No Valid Conclusion

Forty-four premise pairs support no valid conclusion at all, because the premises rule out all possible relationships between A and C. The reason for this is that certain premise combinations are mutually exclusive if it is assumed that explicitly stated instances of negated entities must exist.

\begin{tabular}{|c|c|c|c|}
\hline $\mathrm{A}[\mathrm{nn}] \mathrm{A}[\mathrm{aa}] 1$ & $\mathrm{~A}[\mathrm{nn}] \mathrm{N}[\mathrm{an}] 1$ & $\mathrm{~N}[\mathrm{na}] \mathrm{A}[\mathrm{aa}] 1$ & $\mathrm{~N}[\mathrm{na}] \mathrm{N}[\mathrm{an}] 1$ \\
\hline $\mathrm{A}[\mathrm{nn}] \mathrm{A}[\mathrm{nn}] 1$ & $\mathrm{~A}[\mathrm{nn}] \mathrm{N}[\mathrm{na}] 1$ & $\mathrm{~N}[\mathrm{na}] \mathrm{A}[\mathrm{nn}] 1$ & $\mathrm{~N}[$ na] $\mathrm{N}[$ na $] 1$ \\
\hline $\mathrm{A}[\mathrm{nn}] \mathrm{S}[\mathrm{nn}] 1$ & $\mathrm{~N}[\mathrm{na}] \mathrm{S}[\mathrm{nn}] 1$ & & \\
\hline $\mathrm{S}[\mathrm{nn}] \mathrm{A}[\mathrm{aa}] 1$ & $\mathrm{~S}[\mathrm{nn}] \mathrm{N}[\mathrm{an}] 1$ & & \\
\hline $\mathrm{A}[\mathrm{aa}] \mathrm{A}[\mathrm{nn}] 2$ & $\mathrm{~A}[\mathrm{aa}] \mathrm{N}[\mathrm{na}] 2$ & $\mathrm{~N}[\mathrm{an}] \mathrm{A}[\mathrm{nn}] 2$ & $\mathrm{~N}[\operatorname{an}] \mathrm{N}[\mathrm{na}] 2$ \\
\hline $\mathrm{A}[\mathrm{aa}] \mathrm{S}[\mathrm{nn}] 2$ & $\mathrm{~N}[\operatorname{an}] \mathrm{S}[\mathrm{nn}] 2$ & & \\
\hline $\mathrm{A}[\mathrm{nn}] \mathrm{A}[\mathrm{aa}] 2$ & $\mathrm{~A}[\mathrm{nn}] \mathrm{N}[\mathrm{an}] 2$ & $\mathrm{~N}[\mathrm{na}] \mathrm{A}[\mathrm{aa}] 2$ & $\mathrm{~N}[$ na $] \mathrm{N}[\mathrm{an}] 2$ \\
\hline $\mathrm{S}[\mathrm{nn}] \mathrm{A}[\mathrm{aa}] 2$ & $\mathrm{~S}[\mathrm{nn}] \mathrm{N}[\mathrm{an}] 2$ & & \\
\hline $\mathrm{A}[\mathrm{nn}] \mathrm{A}[\mathrm{nn}] 3$ & $\mathrm{~A}[\mathrm{nn}] \mathrm{N}[\mathrm{na}] 3$ & $\mathrm{~N}[\mathrm{na}] \mathrm{A}[\mathrm{nn}] 3$ & $\mathrm{~N}[\mathrm{na}] \mathrm{N}[\mathrm{na}] 3$ \\
\hline $\mathrm{A}[\mathrm{nn}] \mathrm{S}[\mathrm{nn}] 3$ & $\mathrm{~N}[\mathrm{na}] \mathrm{S}[\mathrm{nn}] 3$ & & \\
\hline $\mathrm{S}[\mathrm{nn}] \mathrm{A}[\mathrm{nn}] 3$ & $\mathrm{~S}[\mathrm{nn}] \mathrm{N}[\mathrm{na}] 3$ & & \\
\hline $\mathrm{A}[\mathrm{aa}] \mathrm{A}[\mathrm{nn}] 4$ & $\mathrm{~A}[\mathrm{aa}] \mathrm{N}[\mathrm{na}] 4$ & $\mathrm{~N}[\mathrm{an}] \mathrm{A}[\mathrm{nn}] 4$ & $\mathrm{~N}[\mathrm{an}] \mathrm{N}[\mathrm{na}] 4$ \\
\hline $\mathrm{A}[\mathrm{aa}] \mathrm{S}[\mathrm{nn}] 4$ & $\mathrm{~N}[\mathrm{an}] \mathrm{S}[\mathrm{nn}] 4$ & & \\
\hline $\mathrm{A}[\mathrm{nn}] \mathrm{A}[\mathrm{nn}] 4$ & $\mathrm{~A}[\mathrm{nn}] \mathrm{N}[\mathrm{na}] 4$ & $\mathrm{~N}[\mathrm{na}] \mathrm{A}[\mathrm{nn}] 4$ & $\mathrm{~N}[$ na $] \mathrm{N}[\mathrm{na}] 4$ \\
\hline $\mathrm{S}[\mathrm{nn}] \mathrm{A}[\mathrm{nn}] 4$ & $\mathrm{~S}[\mathrm{nn}] \mathrm{N}[\mathrm{na}] 4$ & & \\
\hline
\end{tabular}

(Manuscript received May 10, 2004;

revision accepted for publication September 21, 2004.) 